NBER WORKING PAPER SERIES

RETHINKING THE EFFECTS OF FINANCIAL LIBERALIZATION

Fernando A. Broner

Jaume Ventura

Working Paper 16640

http://www.nber.org/papers/w16640

\author{
NATIONAL BUREAU OF ECONOMIC RESEARCH \\ 1050 Massachusetts Avenue \\ Cambridge, MA 02138 \\ December 2010
}

We thank Robert Zymek for excellent research assistance. We received valuable comments from Fernando Alvarez, Vasco Carvalho, Michael Devereux, Nicola Gennaioli, Giacomo Ponzetto, Romain Ranciere, and participants at presentations held at the Banque de France Conference on International Macroeconomics and Finance, Bilkent, CEPR ESSIM, Chicago Fed, Collegio Carlo Alberto, Di Tella-LACEA Workshop in International Economics and Finance, Harvard, Graduate Institute Geneva, IMF Annual Research Conference, LUISS, LSE, Minnesota Workshop on Macroeconomic Theory, MIT, Michigan, Notre Dame, PSE, Sabanci, San Andrés, SED Meetings, UBC, and Wisconsin. We acknowledge financial support from the International Growth Centre, the European Research Council, and the Barcelona GSE The views expressed herein are those of the authors and do not necessarily reflect the views of the National Bureau of Economic Research.

NBER working papers are circulated for discussion and comment purposes. They have not been peerreviewed or been subject to the review by the NBER Board of Directors that accompanies official NBER publications.

(C) 2010 by Fernando A. Broner and Jaume Ventura. All rights reserved. Short sections of text, not to exceed two paragraphs, may be quoted without explicit permission provided that full credit, including (C) notice, is given to the source. 
Rethinking the Effects of Financial Liberalization

Fernando A. Broner and Jaume Ventura

NBER Working Paper No. 16640

December 2010

JEL No. F34,F36,F43,G15,O19,O43

\begin{abstract}
During the last few decades, many emerging markets have lifted restrictions on cross-border financial transactions. The conventional view was that this would allow these countries to: (i) receive capital inflows from advanced countries that would finance higher investment and growth; (ii) insure against aggregate shocks and reduce consumption volatility; and (iii) accelerate the development of domestic financial markets and achieve a more efficient domestic allocation of capital and better sharing of individual risks. However, the evidence suggests that this conventional view was wrong. In this paper, we present a simple model that can account for the observed effects of financial liberalization. The model emphasizes the role of imperfect enforcement of domestic debts and the interactions between domestic and international financial transactions. In the model, financial liberalization might lead to different outcomes: (i) domestic capital flight and ambiguous effects on net capital flows, investment, and growth; (ii) large capital inflows and higher investment and growth; or (iii) volatile capital flows and unstable domestic financial markets. The model shows how these outcomes depend on the level of development, the depth of domestic financial markets, and the quality of institutions
\end{abstract}

Fernando A. Broner

CREI and Universitat Pompeu Fabra

Ramon Trias Fargas, 25-27

08005 Barcelona

Spain

fbroner@crei.cat

Jaume Ventura

CREIIDOCUUniversitat Pompeu Fabra

Ramon Trias Fargas, 25-27

08005-Barcelona

SPAIN

and NBER

jventura@crei.cat 
During the last few decades, many emerging markets have lifted restrictions on cross-border financial transactions. The conventional view, part of the so-called Washington Consensus, was quite optimistic regarding the effects of financial liberalization. An authoritative rendition of such view can be found in a famous speech by Stanley Fischer, Deputy Director of the International Monetary Fund and world leading macroeconomist, who argued that:

"Free capital movements facilitate a more efficient global allocation of savings, and help channel resources into their most productive uses, thus increasing economic growth and welfare. [...] International capital flows have expanded the opportunities for portfolio diversification, and thereby provided investors with a potential to achieve higher riskadjusted rates of returns. And just as current account liberalization promotes growth by increasing access to sophisticated technology, and export competition has improved domestic technology, so capital account liberalization can increase the efficiency of the domestic financial system. [...] These are not abstract concepts, but benefits that every country represented in this room has enjoyed as a result of its access to the international capital markets."

Stanley Fischer, "Capital Account Liberalization and the Role of the IMF," speech at the IMF Annual Meetings, September 19, 1997

Mounting empirical evidence (reviewed later) suggests that this conventional view was wrong however. ${ }^{1}$ Some of the richer emerging markets have indeed received substantial capital flows. But the experience of other rich emerging markets and most of the poorer ones is that capital flows have been quite small or even negative. Overall, there is no evidence that financial liberalization systematically increases investment or growth in emerging markets. Capital flows have also been highly volatile and procyclical, and there is evidence that financial liberalization has increased both output and consumption volatility. There is also evidence that financial liberalization has made domestic financial markets more unstable and prone to crises. Perhaps the most robust finding is that the effects of financial liberalization vary substantially across countries. Specifically, the effects of financial liberalizations depend on whether the liberalizing country is rich or poor, on whether it has developed or underdeveloped financial markets, and on whether it has high- or low-quality institutions.

Why was the conventional view wrong? Our answer is that it failed to anticipate the full effects of financial liberalization on debt enforcement. The conventional view was certainly aware of the

\footnotetext{
${ }^{1}$ In fairness, Fischer also warned that "capital account liberalization increases the vulnerability of the economy to swings in market sentiment," and that "this is a valid concern to those contemplating capital account liberalization, and for the international community." We have much to say in this paper about these swings in market sentiment.
} 
problems associated with the enforcement of foreign debts. After all, most financial liberalizations in emerging markets took place in the aftermath of the 1980s international debt crisis. But this view ignored key interactions between foreign and domestic debts by implicitly assuming that the latter would be enforced even if the former were not. ${ }^{2}$ And yet such discrimination is hardly feasible in real-world financial markets. In the case of bonds and stocks, discriminating against foreigners is difficult because they can resell these assets to domestic residents in secondary markets. ${ }^{3}$ Even when asset trade is intermediated by banks and other financial institutions, discrimination is difficult since it is not possible to know the nationality of the clients of these intermediaries or how default losses would be distributed among them. Finally, courts often abide by equal-treatment rules that limit the possibility of discrimination based on nationality. ${ }^{4}$

The main contribution of this paper is to show that a theory that recognizes the difficulty of discriminating between domestic and foreign creditors can explain the different country experiences after financial liberalization. To do this, we develop a tractable analytical framework that extends the popular Solow model to allow for imperfect debt enforcement. Despite its simplicity, this framework is a rich source of testable hypotheses linking the success or failure of financial liberalization to observable country characteristics such as initial income, savings, the level of productivity, the quality of enforcement institutions and luck. ${ }^{5}$

Let us start by asking why capital flows to some emerging markets have been quite small and sometimes even negative. The conventional view recognized that foreign sources of financing would be risky, as the temptation for opportunistic default combined with low-quality institutions were likely to generate recurrent foreign debt crisis. But it also assumed that domestic savings would stay at home, and the new foreign sources of financing would constitute a net addition to overall development financing. If debt enforcement is not discriminatory however, defaults will not only affect foreign debts but also domestic ones. If defaults happen anyway, domestic savers will find it optimal to send part or all of their savings abroad. This detrimental "capital flight" effect was not anticipated by the conventional view. But it means that financial liberalization not only adds new foreign sources of financing that are cheap but risky, but also subtracts domestic sources of

\footnotetext{
${ }^{2}$ The conventional view builds on an extensive theoretical work (reviewed later) that was motivated by the 1980s debt crisis. This literature highlights the problems associated with enforcing foreign debts, but assumes that domestic debts are always enforced.

${ }^{3}$ See Broner, Martin and Ventura (2008 and 2010).

${ }^{4}$ There are a few recent papers that also assume that debt enforcement/repayment is non-discriminatory. Broner and Ventura (forthcoming) explore the effects of financial liberalization on the degree to which individuals can share risks within and between countries. Kremer and Mehta (2000), Rappoport (2005), Brutti (2008), Gennaioli, Martin, and Rossi (2009), Guembel and Sussman (2009), and Basu (2010) explore the role of non-discrimination in the determination of government debt and tax policy.

${ }^{5} \mathrm{We}$ are not, of course, the first to develop a formal model showing why the conventional view might be wrong. We review below other theoretical papers that do this and relate their findings to ours.
} 
financing that were expensive but safe. This tends to raise gross capital flows but has an ambiguous effect on net capital flows and overall development financing.

Let us ask next why financial liberalization has led to substantial capital flows to some emerging markets that were already somewhat rich. The conventional view was that these countries would benefit from financial liberalization, but probably less so than poorer countries. The reason, of course, is that these countries already had a substantial amount of domestic savings and their needs for foreign financing were less acute. If debt enforcement is not discriminatory however, enforcing domestic debts implies also enforcing foreign ones. If domestic markets are deep enough, the desire to enforce domestic debts reduces or eliminates the temptation for opportunistic default on foreigners. This beneficial "financial depth" effect, which was not anticipated by the conventional view either, lowers the risk of foreign borrowing and raises capital flows.

Let us ask finally why financial liberalization has led to capital flows that are volatile and procyclical and has raised the instability of domestic financial markets. The two effects discussed above suggest that two equilibria are possible depending on investor sentiment. If domestic savers are pessimistic and think that the probability of default is high, they will prefer to send most of their savings abroad. In this case, default affects mostly foreign debts and countries will prefer to default ex-post, confirming the pessimistic beliefs. This equilibrium with small or negative capital inflows always exists. If instead domestic savers are optimistic and think that the probability of default is small, they will keep their savings at home. In this case, default would affect mostly domestic debts and countries will prefer not to default ex-post, confirming the optimistic beliefs. This equilibrium with substantial capital inflows exists only if domestic savings are high relative to foreign borrowing. We describe these equilibria and show how changes in investor sentiment can generate macroeconomic volatility and procyclical capital flows.

Our theory provides an example of how globalization strains existing institutions. We start from a situation in which, despite imperfect enforcement institutions, domestic debts are enforced. After financial liberalization, and despite no institutional change, domestic debts might no longer be enforced. The basic point is that globalization affects policy incentives, sometimes accentuating the shortcomings of imperfect institutions. This simple observation, which is key to understand why the conventional view failed, is a main theme in this paper.

The paper is organized in four sections. Section 1 develops the basic analytical framework used throughout the paper. This is a standard growth model of a capital-scarce country that is not always willing to enforce its foreign debts. In this section, we assume that enforcement is discriminatory and interpret the results as the conventional view. Section 2 considers the same setup but assumes instead that enforcement is non-discriminatory. We analyze the optimistic and 
pessimistic equilibria discussed above, and characterize the conditions for their existence. Section 3 then uses these equilibria to derive the implications of the theory for the effects of financial liberalization. This section collects the main results of this paper, and relates the success of financial liberalization to the underlying country characteristics and luck. Section 4 concludes with some speculative remarks on the potential role of economic policy. Before all of this, we offer a short discussion of the most relevant empirical and theoretical literatures.

\section{Empirical literature:}

There is a vast empirical literature on the effects of financial liberalization. However, this literature is subject to important data limitations. In particular, there is a small number of episodes, financial liberalizations are accompanied by other policy reforms, and countries probably take into account the potential effects of liberalization when deciding whether to liberalize or not. As a result of these data limitations, there is no strong consensus regarding the effects of financial liberalization.

Regarding level effects, there are many cross-country studies that have shown that financial liberalization in developing countries has not led to an increase in investment, growth, or even net capital inflows. See for example Rodrik (1998), Arteta, Eichengreen, and Wyplosz (2001), Edwards (2001), and Bonfiglioli (2008). Henry (2007) argues that liberalizations do increase investment and growth, but that the effects are temporary. Bekaert, Harvey, and Lundblad (2005) argue that stock market liberalizations do increase growth. And Levchenko, Ranciere, and Thoenig (2009) also find positive growth effects when analyzing industry level data. ${ }^{6}$ One robust result in the literature is that the effects of financial liberalization depend on country characteristics. In particular, Arteta, Eichengreen, and Wyplosz (2001), Edwards (2001), Bekaert, Harvey, and Lundblad (2005), Alfaro, Kalemli-Ozcan, and Volosovych (2008), and Papaioannou (2009) show that liberalization in developing countries leads to larger capital inflows, and higher investment and growth in countries with stronger institutions, more developed domestic financial markets, and higher initial income.

Regarding volatility effects, there is some evidence that financial liberalization increases macroeconomic volatility. This was argued for the case of Latin America by Díaz-Alejandro (1985), and in cross-country evidence by Kaminsky and Reinhart (1999) and Kose, Prasad, and Terrones (2003). However, Bekaert, Harvey, and Lundblad (2006) argue that stock market liberalizions lower

\footnotetext{
${ }^{6}$ Another important issue is whether, as suggested by Lucas (1990), the return to capital in developing countries is not higher than in advanced countries due to productivity differences. Caselli and Feyrer (2007) present evidence consistent with this interpretation. However, their methodology is based on the assumption that domestic financial markets work perfectly, which is inconsistent with Banerjee and Duflo's (2005) findings of very large differences in the return to capital within developing countries. Also, during the first wave of financial globalization in the late 19th century, when developing countries were effectively colonies and sovereign risk was less of a problem, capital flows to developing countries were extremely high (see Obstfeld and Taylor, 2004).
} 
consumption volatility. As in the case of level effects, there is robust evidence that the effects of liberalization depend on country characteristics. In particular, Bekaert, Harvey, and Lundblad (2006) and Broner and Rigobon (2006) show that both consumption volatility and the volatility of capital flows is higher in countries with weak institutions and underdeveloped domestic financial markets. Also, Reinhart and Rogoff (2009) use long-run historical data to show that the frequency of crises is a persistent characteristic of countries, although Ranciere, Tornell, and Westermann (2008) provide evidence that countries that are subject to crises grow on average faster than countries that follow a more cautious development strategy. For a thorough review of the effects of financial liberalizations, see the surveys by Prasad, Rajan, and Subramanian (2007), Kose, Prasad, Rogoff, and Wei (2009), and Obstfeld (2009).

There are a number of papers that provide evidence regarding the interactions of domestic and international financial markets emphasized in this paper. In particular, Kaminsky and Reinhart (1999), Borensztein and Panizza (2008), Gennaioli, Martin, and Rossi (2009), and Reinhart and Rogoff (2009) show that domestic financial crises are more frequent during periods of international financial integration, and that defaults on foreign debts are associated with domestic financial crises.

\section{Theoretical literature:}

The theoretical underpinnings of the conventional view were laid out by the maximizing models that took over the field of international economics in the early 1980s. These models were designed to study the pattern of capital flows and their macroeconomic consequences, and sprang from two sources: (i) the so-called intertemporal approach (IA) to the current account studied the case in which the costs of international risk sharing are prohibitive; and (ii) the open-economy versions of the Real Business Cycle (RBC) model went to the other extreme and studied the case in which these costs are negligible. See Obstfeld and Rogoff (1996) for a textbook treatment of these models.

In the case of industrial countries, Ventura (2003) shows that the IA models perform quite well empirically. Instead, RBC models predict much more international risk sharing than observed in the data. This is why a lot of the recent research in the field has focused on explaining why risk sharing is so low among industrial countries. See the surveys by Lewis (1999), Karolyi and Stultz (2003) and Sercu and Vanpée (2007).

In the case of emerging markets, it was recognized early on that neither the IA nor the RBC models would prove appropriate. ${ }^{7}$ Recall that these models were being developed against the background of the worst sovereign debt crisis since the 1930s. Consequently, a new class of models was developed emphasizing the role of strategic default on foreign debts (also called sovereign risk).

\footnotetext{
${ }^{7}$ See Aguiar and Gopinath (2007) for a recent contrarian view.
} 
See the seminal papers by Eaton and Gersovitz (1981), Grossman and van Huyck (1988), Bulow and Rogoff (1989a and 1989b) and Atkeson (1991), and the excellent survey by Eaton and Fernández (1995). ${ }^{8}$ It is widely believed that the predictions of these models for financial liberalization are essentially the same as those of the IA models. Strategic default reduces the size of the effects, but it does not change their nature. ${ }^{9}$ This is the view that we label "conventional" and that we challenge here. Taking as starting point a prototype model of strategic default, we show that this view hinges on the unrealistic assumption that domestic debts are unaffected by default on foreign debts. Once this assumption is removed, the effects of financial liberalization can be quite different from those predicted by the IA models. Our work shows that there is much more to the models of strategic default than what it has been uncovered so far, and that the classic research strategy of extending the IA models to include strategic default has not been exhausted yet.

This is not to say that this is the only useful research strategy, of course. A number of papers have challenged the conventional view by shifting the focus away from macroeconomic or sovereign risk and towards microeconomic frictions in financial markets. In a seminal paper, Gertler and Rogoff (1990) showed that, if wealth plays a role as collateral when borrowing (as it is often the case when various microeconomic frictions are present), autarky interest rates might be lower in capital-scarce countries than in capital-abundant ones, even if the marginal product of capital is higher. This might reverse the predictions of the IA models regarding the pattern of capital flows. Boyd and Smith (1997) and Matsuyama (2004 and 2008) used this insight in related dynamic models to show that financial liberalization can reduce investment and growth in capital-scarce countries. These models have the ability to explain why capital flows towards countries that are already somewhat rich and have developed financial markets. ${ }^{10,11}$

Of course, sovereign risk and microeconomic frictions are both important features of real economies. Caballero and Krishnamurthy (2001) and Tirole (2003) analyze the problem of sovereign risk in the presence of frictions that affect private transactions, and explore various externalities. While Caballero and Krishnamurthy emphasize excessive private risk taking, Tirole focuses

\footnotetext{
${ }^{8}$ Further research after this survey includes Cole and Kehoe (1997), Kletzer and Wright (2000), Wright (2002), Aguiar and Gopinath (2006), Amador (2008), Arellano (2008), Aguiar, Amador, and Gopinath (2009), Bai and Zhang (2010), and Aguiar and Amador (forthcoming).

${ }^{9}$ It might however explain the composition of capital flows. See Kraay, Loayza Servén and Ventura (2005).

${ }^{10}$ Focusing on the macroeconomic effects of microeconomic frictions when studying international capital flows has become quite popular recently. See Shleifer and Wolfenzon (2002), Aoki, Benigno, and Kiyotaki (2006), Caballero, Farhi, and Gourinchas (2008), Antràs and Caballero (2009), Mendoza, Quadrini, and Rios-Rull (2009) and Martin and Taddei (2010), among others.

${ }^{11} \mathrm{~A}$ third, and quite interesting, line of research is that followed by Acemoglu and Zilibotti (1997) who develop a model in which investments are indivisible and show that this is enough to overturn some of the conclusions of the conventional view. In their framework, financial liberalization reduces investment and growth in capital-scarce countries if the world is poor enough, but this trend reverses as the world grows richer. Martin and Rey (2006) have shown that in this framework changes in investor sentiment can also generate macroeconomic volatility and procyclical capital flows.
} 
on the problems that arise when individuals do not internalize how their actions affect government policy. In three recent papers, Brutti (2008), Gennaioli, Martin and Rossi (2009), and Basu (2010) have proposed models in which non-discriminatory defaults on sovereign debt reduce the net worth of investors and thus create turmoil in domestic financial markets. These papers uncover crucial interactions between international and domestic public debt and private financial transactions that are highly complementary to the analysis in this paper.

\section{The conventional view of financial liberalization}

We develop next a stylized model of sovereign risk that captures the standard or conventional view of the effects of financial liberalization. According to this view, financial liberalization allows capitalscarce countries to import capital leading to a surge in consumption, investment and economic growth. Capital flows also make the economy less sensitive to savings shocks and more sensitive to productivity shocks. Imperfect enforcement institutions reduce capital imports, moderating but not reversing these effects.

\subsection{Before financial liberalization}

Consider a small country that initially lives in autarky. This country is inhabited by overlapping generations of young and old. Each generation contains a continuum of individuals of measure one. The young work, earn a wage and save part of it. The old retire and live off their savings. The representative member of generation $t$ (from now on "generation $t$ " for short) maximizes the discounted expected utility of consumption:

$$
U_{t}=u\left(c_{t, t}\right)+\beta \cdot E_{t}\left[u\left(c_{t, t+1}\right)\right]
$$

with $\beta>0, u(\cdot)=\ln (\cdot)$ and $c_{t, t+1}$ is the consumption of generation $t$ in period $t+1$.

The output of the country is given by a Cobb-Douglas production function, $f\left(k_{t}\right)=k_{t}^{\alpha} \cdot l_{t}^{1-\alpha}$ with $\alpha \in(0,1)$, where $k_{t}$ and $l_{t}$ are the country's capital stock and labor force. All individuals supply one unit of labor inelastically when young and, thus, $l_{t}=1$ for all $t$. For each unit of output invested in period $t, A>0$ units of capital are obtained in period $t+1$. Capital fully depreciates in one generation. Markets are competitive and factors of production are paid the value of their marginal product:

$$
w_{t}=(1-\alpha) \cdot k_{t}^{\alpha} \text { and } r_{t}=\alpha \cdot k_{t}^{\alpha-1}
$$

where $w_{t}$ and $r_{t}$ are the wage and the rental rate, respectively. Equation (2) determines how output 
is split between the young generation who owns labor and the old generation who owns capital.

There is no borrowing and lending across generations, since this type of trade requires interactions in two different periods. Since all individuals within a generation are identical, there is no loss of generality in assuming no borrowing and lending within generations, and we can write the budget constraints of generation $t$ as follows:

$$
\begin{aligned}
c_{t, t} & =w_{t}-\frac{k_{t+1}}{A} \\
c_{t, t+1} & =r_{t+1} \cdot k_{t+1}
\end{aligned}
$$

Utility maximization leads each generation to save a fraction $\frac{\beta}{1+\beta}$ of their wage. Since the wage is itself a fraction $1-\alpha$ of output, the savings of the young generation consist of a constant fraction $s$ of the country's output, where $s \equiv \frac{\beta}{1+\beta} \cdot(1-\alpha)$. Since the old do not save, the capital stock is given by:

$$
k_{t+1}=A \cdot s \cdot k_{t}^{\alpha}
$$

Equation (5) is the law of motion of the capital stock before financial liberalization. From any initial positive value, the capital stock monotonically converges to

$$
k_{S S}^{A}=(s \cdot A)^{\frac{1}{1-\alpha}}
$$

These dynamics are very familiar and need no further comment, since they are those of the classic Solow model. Throughout, we assume that it is not possible to increase steady state consumption by reducing the capital stock, that is, the economy is dynamically efficient. This requires that the investment rate be lower than the share of capital, i.e. $s \leq \alpha .{ }^{12}$ This assumption implies that the gross rate of return to capital in the steady state exceeds one:

$$
A \cdot r_{S S}^{A}=\frac{\alpha}{s} \geq 1
$$

\subsection{After financial liberalization}

By financial liberalization we mean the complete removal of legal and technological barriers impeding the inhabitants of the country from accessing the international financial market. We think of this market as containing many infinitesimal individuals from other, unspecified, countries whose

\footnotetext{
${ }^{12}$ See Abel et al. (1989) and Martin and Ventura (2010) for a discussion of this criterion. The latter paper also provides a discussion of bubbly equilibria in a related model. We ignore these equilibria here.
} 
combined size is much larger than that of the country under study. This market is willing and able to buy or sell any bond offering an expected gross return equal to one. This assumption ensures that the country is capital scarce. It also ensures that the world economy is dynamically efficient and, as a result, increases in the capital stock cannot reduce consumption.

The conventional view acknowledges that, even after all technological and legal barriers are removed, the presence of contract enforcement problems might limit access to the international financial market. Let $z_{t+1} \in\{E, N\}$ indicate whether generation $t$ pays its debts when old. Then, the international financial market offers the following contractual rates for borrowing and lending:

$$
R_{t+1}=\frac{1}{\operatorname{Pr}_{t}\left[z_{t+1}=E\right]} \text { and } R_{t+1}^{*}=1
$$

where $R_{t+1}$ is the contractual gross interest rate on one-period bonds issued by the country and sold to the international financial market and $R_{t+1}^{*}$ is the contractual gross interest rate on one-period bonds issued by the international financial market. The expected return on both bonds is the same, as the difference in contractual rates reflects only the probability of default.

The country is endowed with institutions whose objective is to ensure that debts are enforced. ${ }^{13}$ However, these institutions are imperfect and succeed only with probability $\pi \in[0,1]$. The parameter $\pi$ is a measure of the quality of the country's institutions and it plays a key role in the analysis. When institutions succeed, the corresponding generation pays its debts. When institutions fail, the corresponding generation chooses whether to pay its debts or default. Since default raises the consumption and welfare of the generation, default is chosen whenever institutions fail:

$$
\operatorname{Pr}_{t}\left[z_{t+1}=E\right]=\pi
$$

This need not be the case once we go beyond the conventional view since some generations might choose to pay their debts even when institutions fail.

Financial liberalization modifies the budget constraints of generation $t$ as follows:

$$
\begin{aligned}
c_{t, t} & =w_{t}-\frac{k_{t+1}}{A}-\frac{b_{t+1}^{*}}{R_{t+1}^{*}}-\frac{b_{t+1}}{R_{t+1}} \\
c_{t, t+1} & = \begin{cases}r_{t+1} \cdot k_{t+1}+b_{t+1}^{*}+b_{t+1} & \text { if } z_{t+1}=E \\
r_{t+1} \cdot k_{t+1}+b_{t+1}^{*} & \text { if } z_{t+1}=N\end{cases}
\end{aligned}
$$

\footnotetext{
${ }^{13}$ These institutions include law and order and the court system that upholds them, and are affected by the credibility and actions of the country's government. We have argued elsewhere that these institutions should also include secondary markets (see Broner, Martin and Ventura 2008 and 2010). There is a an interesting literature that also examines private enforcement mechanisms (see Dixit 2003).
} 
where $b_{t+1}^{*}$ denotes holdings of bonds issued by the international financial market, and $b_{t+1}$ denotes holdings of bonds issued by generation $t$. Obviously, $b_{t+1}^{*} \geq 0$ and $b_{t+1} \leq 0$.

To determine the law of motion of the capital stock after financial liberalization, we use four intermediate results which are proved in the Appendix:

1. Financial liberalization does not affect the savings of generation $t$, since the income and substitution effects of changes in asset returns cancel in the case of logarithmic utility. That is, $\frac{k_{t+1}}{A}+\frac{b_{t+1}^{*}}{R_{t+1}^{*}}+\frac{b_{t+1}}{R_{t+1}}=s \cdot k_{t}^{\alpha}$.

2. Generation $t$ does not borrow and lend simultaneously since this would increase gross positions, and thus the risk of its portfolio, without affecting its expected return. That is, either $b_{t+1}^{*}>0$ or $b_{t+1}<0$, but not both.

3. If investing all savings at home would lower the return to capital below the world interest rate, then generation $t$ invests up to the point in which the return to capital equals the world interest rate and lends the rest of its savings abroad. That is, if $s \cdot A \cdot k_{t}^{\alpha}>(\alpha \cdot A)^{\frac{1}{1-\alpha}}$, then $b_{t+1}^{*}>0$ and $\alpha \cdot A \cdot k_{t+1}^{\alpha-1}=1$.

4. If investing all savings at home would not lower the return to capital below the world interest rate, then generation $t$ borrows and invests up to the point in which the return to capital equals the world interest rate plus a risk premium that compensates for the fact that producing capital financed by borrowing is risky. That is, if $s \cdot A \cdot k_{t}^{\alpha}<(\alpha \cdot A)^{\frac{1}{1-\alpha}}$, then $b_{t+1}<0$ and $A \cdot \alpha \cdot k_{t+1}^{\alpha-1}=1+(1-\pi) \cdot \frac{\left(-b_{t+1}\right)}{k_{t+1} / A} \cdot 14$

Let $\kappa$ be the value of the capital stock such that the country neither borrows nor lends, i.e. $\kappa \equiv(s \cdot A)^{\frac{1}{1-\alpha}} \cdot\left(\frac{\alpha}{s}\right)^{\frac{1}{\alpha \cdot(1-\alpha)}}$. Then, the law of motion of the capital stock is given by

$$
k_{t+1}=k^{D}\left(k_{t}\right)
$$

where $k^{D}\left(k_{t}\right)$ is defined implicitly by

$$
A \cdot \alpha \cdot k^{D}\left(k_{t}\right)^{\alpha-1}-1= \begin{cases}\frac{1-\pi}{\pi} \cdot \frac{k^{D}\left(k_{t}\right)-A \cdot s \cdot k_{t}^{\alpha}}{k^{D}\left(k_{t}\right)} & \text { if } k_{t}<\kappa \\ 0 & \text { if } k_{t} \geq \kappa\end{cases}
$$

The map $k^{D}(\cdot)$ is continuous but has two differentiated segments. If $k_{t}<\kappa$, the map is strictly increasing and concave. If $k_{t} \geq \kappa$, the map is flat. Figure 1 shows the laws of motion of the capital

\footnotetext{
${ }^{14}$ The risk premium increases with enforcement risk, i.e. $1-\pi$; and leverage or exposure to this risk, i.e. $\frac{\left(-b_{t+1}\right)}{k_{t+1} / A}$.
} 
stock before (dashed line) and after (solid line) financial liberalization, that is, Equations (5) and (11) respectively. Since savings is unaffected by financial liberalization, for each level of capital, the difference between these two lines equals the net foreign asset position of the country. If the country is capital poor, i.e. $k_{t}<\kappa$, financial liberalization shifts the law of motion upwards, indicating that the country imports capital. If the country is instead capital rich, i.e. $k_{t}>\kappa$, financial liberalization shifts the law of motion downwards, indicating that the country exports capital. In any case, from any initial value the capital stock monotonically converges to a steady state defined by:

$$
k_{S S}^{D}=[(\pi \cdot \alpha+(1-\pi) \cdot s) \cdot A]^{\frac{1}{1-\alpha}}
$$

Note that the return to capital is above the world interest rate:

$$
A \cdot r_{S S}^{D}=\frac{\alpha}{\pi \cdot \alpha+(1-\pi) \cdot s} \geq 1
$$

The reason is that importing capital is risky and generation $t$ requires a risk premium to do so.

\subsection{The effects of financial liberalization (I): dynamics}

Let financial liberalization happen in period $t_{L}$, so that the dynamics of the capital stock are given by Equation (5) if $t<t_{L}$, and by Equation (11) if $t \geq t_{L}$. To streamline the discussion assume that the country is below its autarky steady state when financial liberalization happens, i.e. $k_{t_{L}} \leq k_{S S}^{A}$. Thus, the country is capital scarce in the usual sense. What are the main consequences of financial liberalization on a capital scarce country? Broadly speaking, the conventional view points at two main effects of this event on the development path of the country: (i) it raises the steady state capital stock and consumption; ${ }^{15}$ and (ii) it speeds up the convergence towards this steady state.

Figure 2 plots the effects of financial liberalization on the capital stock, consumption and foreign borrowing. All variables are shown as deviations from the values they would have had in the absence of financial liberalization, in the style of impulse-response functions. Since this event does not affect

\footnotetext{
${ }^{15}$ Throughout, we use the term "consumption" to refer to average consumption. This average is computed across individuals and states of nature. Before financial liberalization, the consumptions of the young and old are given by $c_{t+1, t+1}=\frac{1-\alpha}{1+\beta} \cdot k_{t+1}^{\alpha}$ and $c_{t, t+1}=\alpha \cdot k_{t+1}^{\alpha}$. Thus, consumption is defined as:

$$
c_{t+1} \equiv c_{t+1, t+1}+c_{t, t+1}=(1-s) \cdot k_{t+1}^{\alpha}
$$

After financial liberalization, the consumptions of the young and old are given by $c_{t+1, t+1}=\frac{1-\alpha}{1+\beta} \cdot k_{t+1}^{\alpha}$ and $E_{t} c_{t, t+1}=\alpha \cdot k_{t+1}^{\alpha}+s \cdot k_{t}^{\alpha}-\frac{k_{t+1}}{A}$. Therefore, consumption is defined as:

$$
c_{t+1} \equiv c_{t+1, t+1}+E_{t} c_{t, t+1}=(1-s) \cdot k_{t+1}^{\alpha}+s \cdot k_{t}^{\alpha}-\frac{k_{t+1}}{A}
$$
}


savings, capital imports are net additions to capital accumulation. The first young generation after liberalization borrows up to the point in which the return to capital equals the world interest rate plus the appropriate risk premium. Initially this risk premium is high, reflecting the large foreign debt of the country. As the capital stock grows, so does the wealth of the following generations, reducing the need for foreign financing and the risk premium. This leads to further rounds of capital accumulation and debt reduction. In the steady state, the foreign debt stabilizes and the country permanently enjoys a higher capital stock and consumption. Capital imports therefore accelerate economic development, raising investment and growth along the transition and leading to a steady state with higher consumption.

The relative importance of permanent (or steady-state) and transitional (or convergence) effects of financial liberalization depend on the reason why the country is capital poor in the first place. At one extreme, consider a country that is close to its steady state before financial liberalization but has a low savings rate, i.e. $k_{t_{L}} \approx k_{S S}^{A}$ and $s<<\alpha$. For this country, most of the benefits of financial liberalization are permanent, that is, the result of a change in the steady state. At the other extreme, consider a country that is capital poor only because its initial capital stock is low before financial liberalization, but its savings rate is high, i.e. $k_{t_{L}}<<k_{S S}^{A}$ and $s \approx \alpha$. For this country, most of the benefits of financial liberalization are transitory, that is, the result of an increase in the the speed at which the economy converges towards an unchanged steady-state. In between these two extremes, financial liberalization has both permanent and transitory positive effects on capital accumulation.

Interestingly, the increased rate of capital accumulation after financial liberalization is compatible with an increase in consumption in all periods. Capital imports raise wages and lower the rate of return to savings. The first young generation after liberalization does not benefit from higher wages, but still finds that the rate of return to its savings declines. This reduces its old age consumption. But the next generation does benefit from higher wages and this increases its consumption during youth. Unless most of the increase in wages is saved, aggregate consumption increases even in the first period after liberalization. ${ }^{16}$ After this period, consumption is always higher than what it would have been in the absence of financial liberalization.

A key aspect of the conventional view is the notion that the country can take advantage of the development opportunities granted by financial liberalization only if it has good enforcement institutions. To see this, note that the distance between the laws of motion before and after liberalization depend on $\pi$. In the limiting case of perfect institutions, i.e. $\pi \rightarrow 1$, the steady state

\footnotetext{
${ }^{16}$ To be precise, consumption increases if $s<\frac{\alpha}{1+\alpha}$.
} 
increases the most and the whole transition takes place in a single generation. In the opposite limiting case of lack of enforcement institutions, i.e. $\pi \rightarrow 0$, neither the steady state nor the transition towards it are affected by financial liberalization.

\subsection{The effects of financial liberalization (II): shocks}

According to the conventional view, financial liberalization not only affects the country's development path, but it also affects the way it reacts to shocks. In particular, the conventional view says that financial liberalization makes the economy (iii) less sensitive to savings shocks, and (iv) more sensitive to productivity shocks.

To see this, we let the rate of time preference and the efficiency of investment fluctuate stochastically across generations and write them as $\beta_{t}$ and $A_{t}$. For simplicity, we assume that the processes $\beta_{t}$ and $A_{t}$ are i.i.d. and independent of each other. Shocks to the rate of time preference are easy to handle under the natural assumption that each generation knows its own preferences. Shocks to the efficiency of investment are a bit more tricky if generations are uncertain about their own efficiency. We sidestep any complication however by assuming that each generation also knows its own efficiency. ${ }^{17}$ Under these assumptions, Equations (5) and (11) still apply provided that we replace $s$ and $A$ by $s_{t}$ and $A_{t}$ to recognize that these are no longer constants but instead follow some exogenously given stochastic process. We refer to shifts in $s_{t}$ and $A_{t}$ as shocks to "savings" and "productivity" respectively. Since generations cannot trade before they are born, these shocks are uninsurable. Financial liberalization alters their macroeconomic effects though, as we shall see shortly.

An effect of incorporating shocks to savings and productivity is that the capital stock no longer converges to a steady state value $k_{S S}^{D}$, but rather to a steady state interval $\left[\underline{k}_{S S}^{D}, \bar{k}_{S S}^{D}\right]$ within which it fluctuates randomly forever. The lower boundary of the steady state interval $\underline{k}_{S S}^{D}$ satisfies $\underline{k}_{S S}^{D}=k^{D}\left(\underline{\mathrm{k}}_{S S}^{D} ; \underline{s}, \underline{A}\right)$ where $\underline{s}$ and $\underline{A}$ are the lower bounds of the supports of the processes $s_{t}$ and $A_{t}$. The upper boundary $\bar{k}^{S S}$ satisfies $\bar{k}_{S S}^{D}=k^{D}\left(\bar{k}_{S S}^{D} ; \bar{s}, \bar{A}\right)$ where $\bar{s}$ and $\bar{A}$ are the upper bounds of the support of the processes $s_{t}$ and $A_{t}$. The results in the previous section about the effects of financial liberalization on the location of the steady state and the speed of convergence towards it still apply, although now we must remember that the steady state is an interval of capital stocks rather than a single value.

The top panels of Figure 3 shows the impulse-response function of the capital stock (solid line) and consumption (dashed line) to a transitory savings shock before and after financial liberaliza-

\footnotetext{
${ }^{17}$ See Kraay and Ventura (2000) and (2002) for a discussion of the effects of investment risk on capital flows.
} 
tion. ${ }^{18}$ The patterns exhibited by both variables are similar in both cases. The capital stock increases on impact and then slowly returns to its steady state value. Consumption decreases during the shock, then increases in the aftermath of the shock and slowly returns to its steady state value. The main difference between the two responses is quantitative: the reaction of the capital stock and consumption is smaller after financial liberalization than before it. The reason, of course, is the behavior of capital flows. Before financial liberalization, the additional savings of generation $T$ are invested in the country. After financial liberalization, part of these additional savings are used to reduce the foreign debt. As shown in the top panel of Figure 3, the foreign debt declines on impact and then gradually builds up again as the economy returns to its steady state. ${ }^{19}$

The bottom panels of Figure 3 shows the impulse-response function of the capital stock (dashed line) and consumption (solid line) to a transitory productivity shock before and after financial liberalization. ${ }^{20}$ Once again, we see that the patterns exhibited by both variables are similar in both cases. Both the capital stock and consumption increase on impact only to decrease slowly back to their steady state values once the shock has disappeared. The difference between the two responses is once again quantitative: the response of these variables is larger after financial liberalization than before it. The reason, once again, is the behavior of capital flows. Before financial liberalization, generation $T$ did not raise its investment because, in our case of logarithmic utility, savings are not affected by the shock. After financial liberalization, the savings of generation $T$ is still unaffected by the productivity shock. But now this generation can still raise its investment by increasing its foreign debt. The bottom panel of Figure 3 shows that foreign debt increases on impact, then falls once productivity returns to normal.

Financial liberalization therefore affects the volatility of the economic aggregates. If shocks to savings are large and frequent relative to shocks to productivity, financial liberalization lowers volatility. If, instead, shocks to productivity are large and frequent relative to shocks to savings, financial liberalization raises volatility. The reason is that financial liberalization leads to capital flows that dampen the effects of savings shocks and amplify the effects of productivity shocks on the country.

\footnotetext{
${ }^{18}$ In particular, we assume that generation $T$ is more patient than both earlier and later generations, i.e. $s_{T}>s_{t}=s$ for all $t \neq T$. To allow for a clean comparison, we assume that the country had reached the steady state associated with $s_{t}=s$ and $A_{t}=A$ in period $T$ and plot the variables as deviations from this steady state. The only difference between the two sets of responses is that in panel labeled "Autarky" we assume that $T<t_{L}$; while in the panel labeled "Financial liberalization" we assume that $T>t_{L}$.

${ }^{19}$ These time-series results also apply in the cross section. In particular, conditional on a given $k_{t}$, countries with higher $s$ will have higher investment and growth and lower capital inflows. This is consistent with Gourinchas and Jeanne (2009), who find that capital tends to flow out of countries with high investment and growth. Their interpretation of the data also emphasizes the differences in saving rates among developing countries.

${ }^{20} \mathrm{In}$ particular, we assume now that generation $T$ is more productive than both earlier and later generations, i.e. $A_{T}>A_{t}=A$ for all $t \neq T$.
} 
Once again, the conventional view stresses that these effects of financial liberalization depend on the quality of the country's enforcement institutions. In the limiting case of perfect institutions, i.e. $\pi \rightarrow 1$, the capital stock no longer responds to savings shocks and exhibits the largest possible response to productivity shocks. This is just the textbook case in which enforcement problems are absent. In the opposite limiting case of lack of enforcement institutions, i.e. $\pi \rightarrow 0$, the responses of the capital stock to both types of shocks are unaffected by financial liberalization.

\subsection{Discussion}

After the resolution of the debt crisis of the 1980s, many emerging markets turned to financial liberalization thinking that it would provide a fast track to development. Conventional models such as the one above provided the intellectual underpinning for this policy option. According to these models, capital imports would allow emerging markets to speed up the transition towards the steady state and, possibly, even raise the steady state stock of capital and consumption. This could be achieved without sacrifice, as consumption and investment would increase from the very beginning.

The policy implications of this view are well known: first, emerging markets should eliminate restrictions to international trade in assets and use capital imports to finance development and overcome their chronic shortage of savings. Once the financing problem was solved, emerging markets should implement structural reforms that raise productivity and improve institutions, providing the appropriate environment for financial liberalization to be effective. This policy package came to be known popularly as the "Washington Consensus" and, in some form or another, it was adopted by a large number of emerging markets.

A couple of decades later, the evidence on the effects of this policy package is at best mixed, if not at odds with the theory that underlies it. Capital often seems to flow in the wrong direction and its impact on investment and growth is far from clear. Specifically, it seems that this impact depends on whether the liberalizing country is rich or poor, on whether it has developed or underdeveloped domestic financial markets, and on whether it has high- or low-quality institutions. If anything, those countries that seem to benefit more are already somewhat rich with a minimum level of institutions and financial development. This has led many to argue that there exist threshold effects.

Why have conventional models not been successful in accounting for the observed effects of financial liberalizations? We argue next that one possible reason is that they have not paid enough attention to the problem of enforcing domestic debts. This omission is probably due to the widespread use of the representative agent assumption which eliminates domestic trade altogether. In 
the rest of the paper we modify the conventional view by introducing heterogeneity and domestic debts. We show that the resulting interactions between enforcing domestic and foreign debts provide a new and richer view of financial liberalization that goes a long way towards reconciling the theory with the facts.

\section{Enforcement of domestic and foreign payments}

In this section, we introduce heterogeneity within each generation. This creates gains from domestic borrowing and lending and raises the issue of enforcing domestic debts. One possibility is that domestic debts are always enforced, even though foreign debts are not. This assumption underlies the conventional view. We then propose the more realistic assumption that both domestic and foreign debts are imperfectly enforced.

\subsection{The basic setup with domestic trade}

Assume now that only a fraction or measure $\varepsilon \in[0,1]$ of individuals in each generation are capable of converting output when young into capital when old. We refer to this group as "entrepreneurs" and the rest of the generation as "savers." ${ }^{21}$ Let $I_{t}$ be the set of individuals that belong to generation $t$, with typical element $i \in I_{t}$. Then, define the sets of "entrepreneurs" and "savers" as $I_{t}^{E}$ and $I_{t}^{S}$. Naturally, $I_{t}=I_{t}^{E} \cup I_{t}^{S}$ and $\varnothing=I_{t}^{E} \cap I_{t}^{S}$. Throughout, we focus on symmetric equilibria in which all entrepreneurs make the same decisions and all savers make the same decisions. The remaining assumptions are as before. Thus, one way to interpret the conventional view is as the limiting case in which $\varepsilon \rightarrow 1$.

This slight change in the setup generates a role for domestic borrowing and lending, thus raising two natural questions regarding enforcement. The first one refers to how conflict among members of a generation is resolved. When institutions fail, generations must decide whether to enforce debts or not. Typically, there will be conflict as entrepreneurs are debtors and savers are creditors. ${ }^{22} \mathrm{We}$ do not explicitly model the process by which generations make collective decisions. Instead, we assume that these decisions are consistent with two principles: (i) an increase in the consumption of any member of the generation is good; and (ii) a redistribution that reduces consumption inequality within the generation is also good. In particular, we assume that generation $t$ chooses enforcement

\footnotetext{
${ }^{21}$ Technically, we assume that savers can convert one unit of output when young into $\delta \gtrsim 0$ units of capital when old. This ensures that (i) consumption is positive and utility is well defined in and out of equilibrium, and (ii) savers never choose to invest in equilibrium.

${ }^{22}$ In the previous section, this conflict did not arise because all members of the generation were debtors.
} 
at $t+1$ to maximize

$$
c_{t, t+1}-\frac{\omega}{2} \cdot \int_{i \in I_{t}}\left|c_{i t, t+1}-c_{t, t+1}\right|,
$$

where we adopt the convention of using the subscript $i$ for individual variables and omitting the subscript for aggregates or country averages, and $\omega \in(0,1)$ is the weight on the second principle. We assume that $\omega<1$ to ensure that an increase in the consumption of any individual is desirable even if this raises inequality. ${ }^{23}$

The second question is whether it is possible to discriminate between domestic and foreign debts when institutions fail. The effects of financial liberalization depend crucially on the answer to this question. Assume first that it is indeed possible to discriminate. Then, foreign debts are enforced only with probability $\pi$ since defaulting on these debts raises domestic consumption. Moreover, domestic debts are enforced with probability one since enforcing these debts reduce consumption inequality without affecting average consumption. This recreates the conventional view. Competition among entrepreneurs ensures that the interest rate on domestic debts equals the return to capital, i.e. $A \cdot r_{t+1}$, resulting in all members of the generation effectively having the same budget set and making the same consumption choices. Aggregate production and savings are not affected by heterogeneity, and the law of motion of the capital stock is still described by Equations (5) and (11). All the previous analysis of the conventional view goes through.

What difference does it make if we interpret the conventional view as the case of homogeneous individuals or we interpret it instead as the case in which individuals are heterogenous but there is perfect discrimination? The answer is not much, except for the predictions about domestic trade. Under the first interpretation, there should be no domestic trade. Under the second interpretation, there should be domestic trade. Before financial liberalization, savers lend all of their savings to entrepreneurs, and the latter invest these savings for them. After financial liberalization, all members of the generation borrow from abroad the same amount (which is exactly the same amount that the representative member of the generation borrowed in the previous section). Then, savers lend to entrepreneurs not only their own savings but also what they have borrowed from abroad. Entrepreneurs invest their own savings and foreign borrowing, plus the savings and foreign borrowing of the savers. This pattern of trade allows savers and entrepreneurs to optimally share default risk. We find the second interpretation more appealing and, as a result, in what follows we shall think of the conventional view as the case of perfect discrimination.

Assume instead that it is not possible to discriminate. This makes no difference before financial

\footnotetext{
${ }^{23}$ We choose this particular "welfare function" for analytical convenience. All our results would go through with any welfare function satisfying the two principles mentioned in the text. We shall come back to this point in a later footnote.
} 
liberalization. Since enforcing domestic debts reduces inequality and there are no foreign debts, enforcement takes place with probability one. But the inability to discriminate makes a difference after financial liberalization. When institutions fail, the corresponding generation faces an enforcement trade off as it must balance the benefits of enforcing domestic debts against the cost of enforcing foreign debts. The country might choose to enforce foreign debts so as to make sure that domestic debts are also enforced. In this case, all debts are enforced with probability one. But the country might instead choose not to enforce domestic debts in order to avoid enforcing foreign debts. In this case, all debts are enforced with probability $\pi$. We show all of this next. ${ }^{24}$

\subsection{Before financial liberalization}

Unlike the previous setup, we have now domestic debts before financial liberalization and we must find out the equilibrium enforcement choice. To do this, we conjecture first that $\operatorname{Pr}_{t}\left[z_{t+1}=E\right]=1$ and then check whether the resulting trade is consistent with generation $t$ preferring to enforce debts ex-post.

If $\operatorname{Pr}_{t}\left[z_{t+1}=E\right]=1$, entrepreneurs borrow up to the point at which the return to capital equals the interest rate. This means that entrepreneurs do not obtain rents from their superior technology and equally share the country's capital income with savers. Thus, the consumption allocation is

$$
c_{i t, t+1}=\alpha \cdot k_{t+1}^{\alpha} \text { for } i \in I_{t}
$$

Does generation $t$ have an incentive to enforce debts ex-post? If it did not, entrepreneurs would keep all the country's capital income for themselves and the consumption allocation would instead be

$$
c_{i t, t+1}= \begin{cases}\frac{1}{\varepsilon} \cdot \alpha \cdot k_{t+1}^{\alpha} & \text { for } i \in I_{t}^{E} \\ 0 & \text { for } i \in I_{t}^{S}\end{cases}
$$

Substituting these consumption allocations into Equation (13) we find that enforcement is preferred. The intuition is simple: enforcement reduces inequality without affecting average consumption. This validates our initial conjecture proving that enforcement with probability one is indeed an equilibrium. The same logic can be used to show that this equilibrium is unique. ${ }^{25}$

\footnotetext{
${ }^{24}$ In general, any model in which enforcing foreign debts is costly while enforcing domestic debts is valuable would lead to qualitatively similar enforcement choices. See Brutti (2008), Gennaioli, Martin, and Rossi (2009), and Basu (2010) for related models in which enforcing domestic debts is desirable because it leads to higher investment and output.

${ }^{25}$ Conjecture that enforcement takes place with probability $\operatorname{Pr} t\left[z_{t+1}=E\right] \in[\pi, 1)$. Given log utility, both savers and entrepreneurs in generation $t$ consume $\frac{1}{1+\beta} \cdot w_{t}$ when young and $\frac{\beta \cdot \operatorname{Pr}_{t}\left[z_{t+1}=E\right]}{1+\beta} \cdot w_{t} \cdot R_{t+1}$ when old if there is enforcement. However, consumption is higher for entrepreneurs when old if there is no enforcement. Since both capital and bond holdings are the same when old in all states, enforcement would eliminate consumption inequality
} 
We conclude therefore that, in our setup with domestic trade, before financial liberalization the law of motion of the capital stock is still given by Equation (5). This is not surprising since discrimination (or the lack of it) plays a role only when foreigners enter the picture.

\subsection{When enforcement of domestic debts leads to enforcement of foreign debts}

The inability to discriminate makes a difference after financial liberalization since generations must trade off the benefits of enforcing domestic debts against the cost of enforcing foreign debts. We start the analysis of this trade-off by constructing equilibria in which all debts are enforced with probability one. To do this, we conjecture that market participants believe that $\operatorname{Pr}_{t}\left[z_{t+1}=E\right]=1$ and then check whether the resulting trade is consistent with generation $t$ preferring to enforce debts ex-post. We refer to this case as the optimistic one.

If debts are enforced with probability one, borrowing and lending rates are equalized, i.e. $R_{t+1}=$ $R_{t+1}^{*}=1$. Since savers cannot invest, all their savings are allocated to bonds. Since bonds issued by domestic residents and the international financial market are perfect substitutes, any mix of domestic/foreign bond holdings that satisfies

$$
b_{i t, t+1}+b_{i t, t+1}^{*}=s \cdot k_{t}^{\alpha}
$$

with $b_{i t, t+1}^{*} \geq 0$ is a maximizing portfolio for savers. Entrepreneurs can invest and maximization leads them to do so until the return to capital equals the world interest rate:

$$
A \cdot \alpha \cdot k_{t+1}^{\alpha-1}=1
$$

Then, any mix of domestic/foreign bond holdings that satisfies

$$
b_{i t, t+1}+b_{i t, t+1}^{*}=s \cdot k_{t}^{\alpha}-\frac{1}{\varepsilon} \cdot \frac{k_{t+1}}{A}
$$

with $b_{i t, t+1}^{*} \geq 0$ is a maximizing portfolio for entrepreneurs.

The next step is to determine whether the consumption allocation implied by these portfolios is consistent with enforcement, as assumed. Since all individuals receive the same return to their savings and this return equals one, the consumption allocation is

$$
c_{i t, t+1}=s \cdot k_{t}^{\alpha} \text { for } i \in I_{t} .
$$

without affecting its average. Therefore, generation $t$ would actually prefer to enforce debts, which contradicts our initial conjecture. 
Does generation $t$ have an incentive to enforce debts ex-post? If it did not, entrepreneurs and savers would default on their debts and the consumption allocation would instead be:

$$
c_{i t, t+1}= \begin{cases}\frac{1}{\varepsilon} \cdot \alpha \cdot k_{t+1}^{\alpha}+b_{i t, t+1}^{*} & \text { for } i \in I_{t}^{E} \\ b_{i t, t+1}^{*} & \text { for } i \in I_{t}^{S}\end{cases}
$$

where $k_{t+1}$ is determined by Equation (17). Since default affects only domestic debts, its impact on consumption depends on the mix of domestic/foreign bonds in the portfolios of entrepreneurs and savers. In particular, the larger the holdings of foreign bonds by entrepreneurs and savers, the larger their consumption in case of default.

Even though maximization does not uniquely determine the mix of domestic/foreign bonds in the portfolio of individuals, this mix affects the incentives to enforce. To validate our initial conjecture that $\operatorname{Pr}_{t}\left[z_{t+1}=E\right]=1$, we must find a distribution of bond holdings that is consistent with both individual maximization and enforcement of debts. If $k_{t} \geq \kappa$, such a distribution always exists. Since the country is a net creditor, there exist distributions that are consistent with individual maximization such that $\int_{i \in I_{t}} b_{i t, t+1}=0$. With these distributions enforcement reduces inequality without affecting average consumption.

If $k_{t}<\kappa$, the country is a net debtor and all distributions that are consistent with individual maximization are such that $\int_{i \in I_{t}} b_{i t, t+1}<0$. With these distributions enforcement still reduces inequality but it also raises average consumption. To determine whether there exists a distribution of bond holdings such that enforcement is still preferred, it is enough to analyze the distribution that minimizes gross positions. As a result, we consider the (unique) distribution obtained by setting $b_{i t, t+1}^{*}=0$ and determining $b_{i t, t+1}$ residually from Equation (16) for $i \in I_{t}^{S}$ and Equation (18) for $i \in I_{t}^{E}$. Using Equation (13), it can be shown that this allocation leads to enforcement if and only if 26

$$
k_{t} \geq \bar{\kappa} \equiv(1-\omega \cdot(1-\varepsilon))^{\frac{1}{\alpha}} \cdot \kappa .
$$

where $\bar{\kappa}$ is the threshold level of capital such that the optimistic equilibrium exists if the capital stock is above $\bar{\kappa}$, but does not exist if the capital stock is below $\bar{\kappa}$. Since $\bar{\kappa}<\kappa$, there always exist a range of capital stocks such that the country repays its debts even if enforcement institutions fails. The threshold $\bar{\kappa}$ reflects the enforcement trade-off faced by generation $t$. On the one hand, enforcement leads to foreign payments that reduce the average consumption of the generation. On the other

\footnotetext{
${ }^{26}$ To obtain this condition, calculate the objective function in Equation (13) with and without enforcement by substituting the consumption allocations in Equations (19) and (20), setting $b_{i t+1}^{*}=0$ for all $i \in I_{t}$. The calculation is simplified by the fact that, regardless of enforcement, $\left|c_{i t, t+1}-c_{t, t+1}\right|=c_{t, t+1}-c_{i t, t+1}$ for $i \in I_{t}^{S}$ and $\left|c_{i t, t+1}-c_{t, t+1}\right|=c_{i t, t+1}-c_{t, t+1}$ for $i \in I_{t}^{E}$.
} 
hand, enforcement leads to domestic payments that reduce inequality within the generation. The higher the capital stock, the higher is the fraction of investment financed with domestic savings. This lowers foreign payments and raises domestic ones, increasing the incentives to enforce. Thus, there exists a threshold level for the capital stock such that enforcement is preferred for all capital stocks above that threshold and not preferred for all capital stocks below it.

What prevents the generation from defaulting on its foreign debt is a distaste for the inequality that default would bring about. This is why the threshold level of capital depends on $\varepsilon$ and $\omega$. If default creates negligible inequality, i.e. $\varepsilon \rightarrow 1$; or this inequality is not perceived as a problem, i.e. $\omega \rightarrow 0$; then nothing prevents generation $t$ from defaulting on its debt whenever this debt is positive, i.e. $k_{t}<\kappa$. If default leads to extreme inequality, i.e. $\varepsilon \rightarrow 0$; and this inequality is perceived as a serious problem, i.e. $\omega \rightarrow 1$; then generation $t$ never defaults on its debts. ${ }^{27}$

We conclude then that, for high enough levels of capital, there exists an equilibrium in which enforcement takes place with probability one. In this equilibrium, $k_{t+1}$ is the level that equalizes the return to capital and the world interest rate. Thus, under the optimistic equilibrium the law of motion of the capital stock is given by

$$
k_{t+1}=k^{O} \equiv(\alpha \cdot A)^{\frac{1}{1-\alpha}} \quad \text { if } k_{t} \geq \bar{\kappa},
$$

Figure 4 shows the laws of motion of the capital stock before financial liberalization (dashed line) and after financial liberalization in this equilibrium (upper solid line), that is, Equations (5) and (22) respectively. ${ }^{28}$ With optimism, the effects of financial liberalization on the law of motion of the capital stock are qualitatively similar to and quantitatively stronger than those of the conventional view. The flat segment that characterizes the law of motion of the conventional view is extended towards the left and applies even if the country imports capital.

What happens if this equilibrium does not exist? Even if this equilibrium exists, is it unique? Or are there other equilibria? If so, how do these equilibria look like? The analysis of the case of non-discrimination is not complete yet.

\footnotetext{
${ }^{27}$ The distribution of asset holdings that maximizes the incentive to enforce is characterized by savers consuming zero in case of default. This is because their only source of income when old are domestic debts. Of course, with any welfare function that penalizes infinitely zero consumption (e.g. average utility with log utility) the enforcement condition would always be satisfied. This is not a robust result though, since in general individuals have other sources of income. For example, individuals might receive wages or pension payments when old. Also, if there were other sources of risk, even in the optimistic equilibrium savers would choose diversified portfolios including both domestic and foreign debts.

${ }^{28}$ For the time being, ignore the bottom solid line.
} 


\subsection{When default on foreign debts leads to default on domestic debts}

We construct next equilibria in which all debts are enforced with probability $\pi$. We refer to this case as the pessimistic one. We conjecture that market participants believe that $\operatorname{Pr}_{t}\left[z_{t+1}=E\right]=\pi$ and, once again, then check whether the resulting trade is consistent with generation $t$ preferring not to enforce debts ex post.

If debts are enforced with probability $\pi$, borrowing and lending rates differ, i.e. $R_{t+1}=\frac{1}{\pi}$ and $R_{t+1}^{*}=1$. Since savers cannot invest, all their savings are still allocated to bonds. But now bonds issued by domestic residents and the international financial market are imperfect substitutes. Both types of bond deliver the same expected return, but domestic bonds are risky while foreign bonds are not. Since savers are risk averse, the former are more attractive and their maximizing portfolio is now:

$$
b_{i t, t+1}=0 \text { and } b_{i t, t+1}^{*}=s \cdot k_{t}^{\alpha}
$$

Entrepreneurs can invest, but borrowing to do so is a risky activity. As a result, maximization leads them to borrow until the return to capital equals the world interest rate plus the appropriate risk premium:

$$
A \cdot \alpha \cdot k_{t+1}^{\alpha-1}=1+(1-\pi) \cdot \frac{\left(-b_{i t, t+1}\right)}{k_{i t, t+1} / A}
$$

The intuition for this risk premium is the same as in the conventional view, namely, a compensation for borrowing risk. To reduce risk in their portfolios, entrepreneurs minimize their gross positions and this leads to this maximizing portfolio:

$$
b_{i t, t+1}=\min \left\{s \cdot k_{t}^{\alpha}-\frac{1}{\varepsilon} \cdot \frac{k_{t+1}}{A}, 0\right\} \quad \text { and } \quad b_{i t, t+1}^{*}=\max \left\{s \cdot k_{t}^{\alpha}-\frac{1}{\varepsilon} \cdot \frac{k_{t+1}}{A}, 0\right\}
$$

The next step is to check whether the consumption allocation implied by these portfolios is consistent with lack of enforcement when institutions fail, therefore validating the initial conjecture that $\operatorname{Pr}_{t}\left[z_{t+1}=E\right]=\pi$. But it is evident that this must be the case. Since savers only hold foreign bonds, the only consequence of enforcement is to force entrepreneurs to pay foreign debts. This is never preferred.

There always exists therefore an equilibrium in which enforcement takes place with probability $\pi$. In this equilibrium, $k_{t+1}$ is the level that equalizes the return to capital to the world interest rate plus the appropriate risk premium. Thus, under the pessimistic equilibrium the law of motion of the capital stock is given by

$$
k_{t+1}=k^{P}\left(k_{t}\right)
$$


where $k^{P}\left(k_{t}\right)$ is defined implicitly by

$$
A \cdot \alpha \cdot k^{P}\left(k_{t}\right)^{\alpha-1}-1= \begin{cases}\frac{1-\pi}{\pi} \cdot \frac{k^{P}\left(k_{t}\right)-A \cdot \varepsilon \cdot s \cdot k_{t}^{\alpha}}{k^{P}\left(k_{t}\right)} & \text { if } k_{t}<\varepsilon^{-\frac{1}{\alpha}} \cdot \kappa \\ 0 & \text { if } k_{t} \geq \varepsilon^{-\frac{1}{\alpha}} \cdot \kappa\end{cases}
$$

Figure 4 shows this law of motion (bottom solid line). For low levels of capital, financial liberalization shifts the law of motion upwards, indicating that the country imports capital. For higher levels of capital, financial liberalization shifts the law of motion downwards, indicating that the country exports capital. Crucially, there is always a set of capital stocks lower than $\kappa$ for which the country exports capital even though it is capital scarce. This observation will play a key role in the discussion of the next section.

Some intuition on the nature of the pessimistic equilibrium can be obtained by noticing that Equation (26) is a downward shift of the law of motion of the conventional view, i.e. Equation (11). In fact, as $\varepsilon \rightarrow 1$, these two laws of motion converge. Why are capital imports and investment lower in the pessimistic equilibrium than in the conventional view? The answer lies in the amount of borrowing risk that entrepreneurs face. In the conventional view, entrepreneurs can borrow from savers without risk. Thus, the total amount of funds available for investment that are not subject to borrowing risk consists of the country's savings, i.e. $s \cdot k_{t}^{\alpha}$. In the pessimistic equilibrium, entrepreneurs can no longer borrow from savers without risk. Thus, the total amount of funds available for investment that are not subject to borrowing risk consists only of the entrepreneurs' own savings, i.e. $\varepsilon \cdot s \cdot k_{t}^{\alpha}$. This makes entrepreneurs more reluctant to borrow and lowers investment and the capital stock.

This also explains why a capital-scarce country always imports capital in the conventional view, while it is possible for a capital-scarce country to export capital in the pessimistic equilibrium. In fact, we can use Equations (5) and (26) to find that there is a threshold level of capital such that the country exports capital in the pessimistic equilibrium:

$$
k_{t}>\hat{\kappa} \equiv\left(\frac{\pi}{1-\varepsilon \cdot(1-\pi)}\right)^{\frac{1}{\alpha \cdot(1-\alpha)}} \cdot \kappa
$$

Since $\hat{\kappa}<\kappa$, there always exist a range of capital stocks such that the country is capital scarce and yet it exports capital. ${ }^{29}$ The threshold level $\hat{\kappa}$ increases with the quality of enforcement institutions. As $\pi \rightarrow 0$, we have that $\hat{\kappa} \rightarrow 0$; while as $\pi \rightarrow 1$ we have that $\hat{\kappa} \rightarrow \kappa$.

\footnotetext{
${ }^{29}$ To gain intuition, consider the limit as borrowing risk tends to infinity. In the conventional view, investment equals domestic savings: $\lim _{\pi \rightarrow 0} k_{t+1}=s \cdot A \cdot k_{t}^{\alpha}$. That is, the country neither imports nor exports capital. In the pessimistic equilibrium, however, investment equals the entrepreneurs' savings: $\lim _{\pi \rightarrow 0} k_{t+1}=\varepsilon \cdot s \cdot A \cdot k_{t}^{\alpha}$. This means that the country exports capital.
} 
Finally, we show that there are no other equilibria beyond the optimistic and pessimistic ones. To do this, conjecture that $\operatorname{Pr}_{t}\left[z_{t+1}=E\right] \in(\pi, 1)$. Risk averse savers prefer foreign bonds to domestic ones and their maximizing portfolio is given by Equation (25). Entrepreneurs only borrow from foreigners. As a result, enforcement does not affect savers and only forces entrepreneurs to pay their debts to foreigners. Thus, generation $t$ prefers not to enforce debts and this contradicts the initial conjecture.

\subsection{Equilibria without discrimination}

A key feature of the theory developed here is that beliefs about enforcement might be self-fulfilling. As a result, a full description of equilibrium requires us to make assumptions about these beliefs. We say that period $t$ is optimistic if market participants in this period believe that $\operatorname{Pr}_{t}\left[z_{t+1}=E\right]=1$. We say that period $t$ is pessimistic if market participants in period $t$ believe that $\operatorname{Pr}_{t}\left[z_{t+1}=E\right]=\pi$. Then, the law of motion of the capital stock can be written as follows:

$$
k_{t+1}= \begin{cases}k^{O} & \text { if } \operatorname{Pr}_{t}\left[z_{t+1}=E\right]=1 \\ k^{P}\left(k_{t}\right) & \text { if } \operatorname{Pr}_{t}\left[z_{t+1}=E\right]=\pi\end{cases}
$$

As is usually done in models with multiple equilibria, we assume that expectations or beliefs are driven by sunspots. The sunspot materializes before savings and investment decisions are made in each period $t$ and determines the beliefs of generation $t$. If the sunspot takes the value "optimistic," the optimistic equilibrium is played if it exists. Otherwise, the pessimistic equilibrium, which always exists, is played. Let $p_{t}$ be the probability that the sunspot take the value optimistic.

If $k_{t}<\bar{\kappa}$, only pessimistic beliefs are self-fulfilling and we have that:

$$
\operatorname{Pr}_{t}\left[z_{t+1}=E\right]=\pi \text { if } k_{t}<\bar{\kappa}
$$

If $k_{t} \geq \bar{\kappa}$ instead, both optimistic and pessimistic beliefs are self-fulfilling. In this case, we have that:

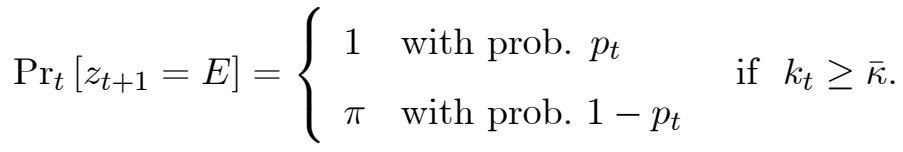

Theory does not impose any restriction on the stochastic process governing $p_{t}$. Thus, we shall emphasize those results that do not depend on the characteristics of this process. To avoid some knife-edge solutions, we shall also assume that $p_{t} \in(0,1)$ for all $t$. This implies that, if $k_{t} \geq \bar{\kappa}$, there is always some uncertainty about the equilibrium that will be played.

To characterize the dynamics of this system it is useful to define the pessimistic steady state as 
the limiting state of an economy in which $\operatorname{Pr}_{t}\left[z_{t+1}=E\right]=\pi$ for all $t$. In this limiting state, the capital stock is given by:

$$
k_{S S}^{P} \equiv[(\pi \cdot \alpha+(1-\pi) \cdot \varepsilon \cdot s) \cdot A]^{\frac{1}{1-\alpha}}
$$

Then, we have the following result:

1. If $k_{S S}^{P}<\bar{\kappa}$, the capital stock converges to $k_{S S}^{P}$. If the initial position is below the threshold $\bar{\kappa}$ this convergence is monotonic. If the initial position is above the threshold $\bar{\kappa}$, fluctuations in investor sentiment generate fluctuations in the capital stock until a long enough sequence of pessimism eventually takes the economy below the threshold. After this, optimism is no longer possible and the capital stock monotonically converges to $k_{S S}^{P}$.

2. If $k_{S S}^{P} \geq \bar{\kappa}$, the capital stock converges to the steady state interval $\left[k_{S S}^{P}, k_{S S}^{O}\right]$, where $k_{S S}^{O} \equiv$ $(\alpha \cdot A)^{\frac{1}{1-\alpha}}$. Abusing the language somewhat, we refer to $k_{S S}^{O}$ as the optimistic steady state. Once this interval is reached, the capital stock fluctuates forever within it. From any initial position, convergence to the steady state is monotonic.

To provide some economic intuition for this result, use the definitions of $k_{S S}^{P}$ and $\bar{\kappa}$ to show that:

$$
k_{S S}^{P}<\bar{\kappa} \Longleftrightarrow \frac{\pi \cdot\left(\frac{s}{\alpha}\right)^{\frac{1-\alpha}{\alpha}}+(1-\pi) \cdot \varepsilon \cdot\left(\frac{s}{\alpha}\right)^{\frac{1}{\alpha}}}{(1-\omega \cdot(1-\varepsilon))^{\frac{1-\alpha}{\alpha}}}<1
$$

That is, the country converges to the pessimistic equilibrium $k_{S S}^{P}$ if it has a low savings rate (low $s$ ), bad enforcement institutions (low $\pi$ ) and generations do not care much about the inequality created by defaults (low $\omega$ ). When such a collection of "bad" country characteristics is present optimism is, at most, a transitory situation. Only pessimism exists in the long run. Conversely, the country converges to the steady state interval $\left[k_{S S}^{P}, k_{S S}^{O}\right]$ if it has a high savings rate (high $s$ ), good enforcement institutions (high $\pi$ ) and generations dislike the redistributions generated by defaults (high $\omega$ ). These "good" country characteristics do not rule out pessimism, but they make optimism possible.

\section{Rethinking the effects of financial liberalization}

The conventional view adopts the representative agent assumption, implicitly assuming that all domestic debts are enforced even when foreign ones are not. We have kept all the assumptions that characterize this view, except for this single one. Instead, we have assumed that such discrimination 
is not possible. We describe next how this apparently small change leads to a major rethinking of the effects of financial liberalizations.

\subsection{The effects of financial liberalization (I): dynamics}

Since financial liberalization happens in period $t_{L}$, the dynamics of the country are given by Equation (5) if $t<t_{L}$, and by Equations (27), (28), and (29) if $t \geq t_{L}$. We ask again about the consequences of this event in a capital-scarce country. Recall that the conventional view is that financial liberalization (i) raises the steady state capital stock and consumption; and (ii) speeds up the convergence to this steady state. Without discrimination, we obtain a non-conventional view of the effects of financial liberalization that can be quite different.

Figure 5 plots the effects of financial liberalization on the capital stock, consumption and foreign borrowing without discrimination. As in Figure 2 (which plots the alternative case with discrimination), all variables are shown as deviations from the values they would have had in the absence of financial liberalization. Figure 5 is drawn for the case of a country such that $k_{t_{L}}<\hat{\kappa}<\bar{\kappa}<k_{S S}^{P}$, that is, for the case depicted in Figure 4. The first interesting aspect of the dynamics depicted in Figure 5 is that the effects of financial liberalization vary over time, as the country goes through three differentiated phases. In the first two of them, only pessimism is possible. In the third and last phase, optimism is possible too.

The first phase is that in which $k_{t_{L}} \leq k_{t}<\hat{\kappa}$. In this phase financial liberalization has the same qualitative effects as in the conventional view: the country borrows to accelerate capital accumulation and increase consumption simultaneously. This raises growth and speeds up convergence to the steady state. Quantitatively, these effects are smaller here than in the conventional view. The reason is that, unlike the conventional view, the risk of default induces savers to place their savings abroad and these no longer constitute a source of riskless funds for entrepreneurs. As domestic lending dries up, entrepreneurs turn to the international financial market to finance their high-return investments. But foreign borrowing is riskier than the domestic borrowing that it substitutes. For each level of investment, the risk premium is now higher than in the conventional view and, as a result, entrepreneurs borrow less than in the case of discrimination of Figure 2. Despite this, in this first phase the borrowing by entrepreneurs still exceeds the lending by savers, and the country as a whole is importing capital. Since savings are unaffected by financial liberalization, capital imports raise investment and growth.

As time goes on, generations become richer leading savers to lend more abroad and entrepreneurs to borrow less from abroad. This means that capital imports decline. Eventually the country becomes a net creditor and this starts the second phase of financial liberalization, i.e. that in 
which: $\hat{\kappa} \leq k_{t}<\bar{\kappa}$. Despite being capital scarce, in this phase the country ends up exporting capital and this lowers investment and growth. The cost of borrowing is on average lower than in autarky, but it is also riskier and this second effect now dominates. Initially, the capital stock and consumption still remain above the levels that these variables would have had in the absence of financial liberalization. But this only reflects the accumulated gains during the first phase. Eventually, the drop in investment and growth catches up and the capital stock and consumption become lower than they would have been in the absence of financial liberalization. By this time, financial liberalization has slowed down the convergence process.

Even then, the country keeps growing at a positive rate and eventually enters the third phase in which $\bar{\kappa} \leq k_{t}$ and optimism becomes possible. If beliefs remain pessimistic, entering this third phase makes no difference whatsoever. But there is a period (Figure 5 assumes this is the first period in which optimism is possible) in which there is a change in investor sentiment and market participants become optimistic. Savers keep their savings in the country, and entrepreneurs expand their borrowing and investment until the marginal product of capital equals the world interest rate. This leads to a surge in capital imports and the country converges to the optimistic steady state $k_{S S}^{O}$ in a single generation. While optimism continues, the country enjoys high levels of capital and consumption, plus financial stability.

Eventually, however, a change in investor sentiment leads to pessimism and generates what, following an large literature on this topic, we describe as a "sudden stop" of capital imports. ${ }^{30}$ Savers send their savings abroad and entrepreneurs cut back on their investments as borrowing becomes risky again. The country starts exporting capital and the capital stock and consumption fall, gradually approaching the pessimistic steady state $k_{S S}^{P}$. When enforcement institutions are imperfect, sudden stops of this sort are recurrent. The long-run average capital stock and its volatility depend on both the size of the steady state interval, i.e. $\left[k_{S S}^{P}, k_{S S}^{O}\right]$; and the properties of the sunspot, i.e. $p_{t}$. In all cases (and in the absence of additional shocks), financial liberalization increases the volatility of the capital stock in the long run. Its effect on the long-run average capital stock and net foreign borrowing is ambiguous, since $k_{S S}^{P}<k_{S S}^{A}<k_{S S}^{O}$.

Figure 5 provides a stylized account of financial liberalization without discrimination. The picture that emerges is much richer than the conventional view. We discuss next the role of various country characteristics in determining the effects of financial liberalization. In particular, we focus on the initial level of development $\left(k_{t_{L}}\right)$, productivity $(A)$, the quality of enforcement institutions $(\pi)$ and savings $(s)$ :

\footnotetext{
${ }^{30}$ The term sudden stop was introduced by Dornbusch, Goldfajn, and Valdés (1995).
} 
1. (Initial level of development) Figure 5 shows the case of a country that liberalizes at a low level of development and goes through three different phases. During the initial phase, the country imports capital and growth accelerates. If financial liberalization takes place at an intermediate level of development, i.e. if $\hat{\kappa}<k_{t_{L}}<\bar{\kappa}$, the country skips this phase and enters directly into the second phase. Thus, financial liberalization leads to capital exports and slows down growth. If financial liberalization takes place instead at high levels of development, i.e. $\bar{\kappa}<k_{t_{L}}$, the country skips the first two phases and moves directly to the third phase in which both the pessimistic and optimistic equilibria exist. In this case, financial liberalization leads to capital imports and higher growth if beliefs are optimistic, but to capital exports and lower growth if beliefs are pessimistic. In any case, financial liberalization creates a recurrent cycle of high- and low-growth periods.

2. (Productivity) In this model, $A$ scales up all laws of motion by the same factor and therefore does not fundamentally affect the results. As is common in growth theory, we could have expressed the capital stock adjusted by productivity, i.e. $\hat{k}_{t}=A^{-\frac{1}{1-\alpha}} \cdot k_{t}$. All the results derived in the previous point for the initial capital stock would apply to this quantity. That is, what matters for the dynamics of the economy is the productivity-adjusted capital stock, and not the capital stock by itself.

3. (Quality of enforcement institutions) As $\pi$ increases relative to the case in Figure 5, the threshold $\hat{\kappa}$ increases while the threshold $\bar{\kappa}$ is unaffected. As a result the second phase becomes shorter and might not even exist. Moreover, in the third phase the steady state interval becomes narrower and this leads to smaller fluctuations and a higher average capital stock. As $\pi$ decreases relative to the case in Figure 5, the pessimistic steady state becomes lower and eventually we get to the case in which $k_{S S}^{P}<\bar{\kappa}$. In this case, the third phase disappears as the fundamentals cannot support optimism.

4. (Savings) Changes in $s$ do no affect the relative position of the two thresholds $\hat{\kappa}$ and $\bar{\kappa}$. As $s$ increases relative to the case in Figure 5, the law of motion under pessimism becomes closer to that under optimism and, as a result, we have that the average capital stock increases and its volatility decreases. As $s$ decreases relative to the case in Figure 5, the opposite occurs. If $s$ falls enough, eventually we find that $\hat{\kappa}<k_{S S}^{P}<\bar{\kappa}$ or even $k_{S S}^{P}<\hat{\kappa}<\bar{\kappa}$. That is, the country reaches the new steady state and stops growing before leaving the second or even the first phase.

As this analysis shows, without discrimination, it is not in general the case that financial 
liberalization in a capital scarce country raises the steady state capital stock and consumption and speeds up the convergence process towards this steady state. The effects of financial liberalization on the growth process are much richer than this and depend in a subtle but quite clear way on the specific characteristics of the country that is liberalizing.

\subsection{The effects of financial liberalization (II): shocks}

In the conventional view, financial liberalization makes the economy (iii) less sensitive to savings shocks, and (iv) more sensitive to productivity shocks. As we show next, when enforcement is nondiscriminatory the effects of shocks after financial liberalization can be quite different.

As in the case of discriminatory enforcement, we can easily extend the model with nondiscriminatory enforcement by letting the discount factor $\beta_{t}$ and the investment productivity $A_{t}$ fluctuate stochastically across generations. ${ }^{31}$ Recall that in the absence of shocks, the economy either converged to a steady state, $k_{S S}^{P}$, in which only the pessimistic equilibrium exists or to a steady state interval, $\left[k_{S S}^{P}, k_{S S}^{O}\right]$, over which both equilibria exist. If the support of the shocks is not too wide, these long-run dynamics are not qualitatively affected, except that now in both cases the economy converges to steady state intervals. If instead the support of the shocks is wide enough, these intervals overlap and "connect" states in which only the pessimistic equilibrium exists and states in which both equilibria exist. In this case, the economy converges to a steady state interval such that sometimes only the pessimistic equilibrium exists and sometimes both equilibria exist. $^{32}$ The results of the previous section on the location of the steady state and the speed of convergence towards it still apply, even if shocks enlarge the steady state interval and make the two key thresholds $\hat{\kappa}_{t}$ and $\bar{\kappa}_{t}$ now a function of the shocks.

The most obvious difference between the non-conventional view developed here and the conventional view presented in section 2 is that, if $k_{t} \geq \bar{\kappa}_{t}$, financial liberalization creates a new source of shocks, namely, self-fulfilling shifts to investor sentiment or sudden stops. These shifts

\footnotetext{
${ }^{31}$ As before, we assume that each generation knows both $\beta_{t}$ and $A_{t}$ when making its savings and investment decisions. As a result, Equations (27), (28), and (29) still apply provided we replace $s$ and $A$ by $s_{t}$ and $A_{t}$. As in section 1.4, we assume that the processes $\beta_{t}$ and $A_{t}$ are i.i.d. and independent of each other.

${ }^{32}$ This happens when the following two conditions hold:

$$
\frac{\pi \cdot\left(\frac{\underline{s}}{\alpha}\right)^{\frac{1-\alpha}{\alpha}}+(1-\pi) \cdot \varepsilon \cdot\left(\frac{\underline{s}}{\alpha}\right)^{\frac{1}{\alpha}}}{(1-\omega \cdot(1-\varepsilon))^{\frac{1-\alpha}{\alpha}}} \cdot \frac{A}{\bar{A}}<1<\frac{\pi \cdot\left(\frac{\bar{s}}{\alpha}\right)^{\frac{1-\alpha}{\alpha}}+(1-\pi) \cdot \varepsilon \cdot\left(\frac{\bar{s}}{\alpha}\right)^{\frac{1}{\alpha}}}{(1-\omega \cdot(1-\varepsilon))^{\frac{1-\alpha}{\alpha}}} \cdot \frac{\bar{A}}{\underline{A}}
$$

The first inequality guarantees that, even if the economy starts at a high level of capital such that both equilibria exist, after a long enough sequence of pessimism, low savings $\underline{s}$, and low productivity $\underline{A}$, the optimistic equilibrium ceases to exist if savings remain low at $\underline{s}$ and productivity increases to $\bar{A}$. The second inequality guarantees that, even if the economy starts at a low level of capital such that only the pessimistic equilibrium exists, after a long enough sequence of high savings $\bar{s}$ and high productivity $\bar{A}$, the optimistic equilibrium becomes possible if savings remain high $\bar{s}$ and productivity drops to $\underline{A}$.
} 
have been modeled with the help of a sunspot variable that takes the value optimism with some exogenously given probability $p_{t}$. Optimistic periods are characterized by capital imports, high investment and growth. Pessimistic periods are characterized by capital exports, low investment and growth. Shocks to investor sentiment differ from standard shocks to savings and productivity in that they do not affect aggregate resource constraints. Instead, they capture the notion of the country getting into and out of a coordination failure. Unless financial liberalization also makes the economy less sensitive to standard shocks to savings and productivity, a first implication is that aggregate volatility will increase. Ceteris paribus, this increase in volatility is higher in countries with low level of development $\left(k_{t_{L}}\right)$, high productivity $\left(A_{t}\right)$, low quality of enforcement institutions $(\pi)$, and low savings $\left(s_{t}\right)$.

A second and more subtle implication is the possibility that standard shocks to savings and productivity have new and non-conventional effects through changes in investor sentiment. This might happen if shocks to savings and productivity move the country in and out of the region in which optimism is possible, i.e. the shocks move the economy from $k_{t} \geq \bar{\kappa}_{t}$ to $k_{t}<\bar{\kappa}_{t}$ or viceversa. Shocks to savings and productivity might also affect investor sentiment if these shocks are used by market participants to coordinate to pessimism or optimism, i.e. when the sunspot depends on exogenous shocks.

Once we allow for interactions between shocks to savings and productivity and investor sentiment, the theory becomes much richer and might lead to somewhat surprising results. ${ }^{33}$ Consider, for instance, the case of a country that is initially in the region where the optimistic equilibrium is not possible and experiences a transitory positive shock to savings. This case is plotted in the top-left panel of Figure 6. The increase in savings makes optimism possible, leading savers to keep their savings at home, and creating an investment boom that raises future capital. This means that optimism remains possible even after the shock to savings is gone. Thus, a transitory increase in savings leads to a surge in capital imports, and a large and persistent increase in investment and growth. Conversely, a reduction in savings may make optimism impossible, leading to capital exports and a large and persistent reduction in investment and growth. The top-right panel of Figure 6 shows this case. These two panels illustrate an important result, which was first discussed in the previous section: increases in savings lower $\bar{\kappa}_{t}$, sometimes making optimism possible and raising capital imports. This prediction is just the opposite as the one we would get from the textbook model which says that increases in savings should reduce capital imports.

\footnotetext{
${ }^{33}$ In the absence of these interactions, the effects of shocks to savings and productivity are essentially the same as in the conventional view. Namely, financial liberalization makes the economy less sensitive to savings shocks, and more sensitive to productivity shocks. The only difference is that these effects are stronger in optimistic periods than in pessimistic ones.
} 
Consider now the case of a country that came from an optimistic period and experiences a transitory increase in productivity. This case is shown in the bottom-left panel of Figure 6 . The increase in productivity makes optimism impossible, leading savers to put their savings abroad and entrepreneurs to cut back their investments. The result is a collapse in capital imports which turn to exports, and a drop in investment and growth. This means that optimism is not possible even after the productivity shock is gone. Thus, a transitory increase in productivity leads to a collapse in capital imports, and a large and persistent decline in investment and growth. Conversely, a reduction in productivity may make optimism possible, leading to capital imports and a large and persistent increase in investment and growth. The bottom-right panel of Figure 6 plots this case. These two panels illustrate another important result, which was first discussed in the previous section: increases in productivity raise $\bar{\kappa}_{t}$, sometimes making optimism impossible and reducing capital imports. This prediction is again just the opposite as the one we would get from the textbook model which says that increases in productivity should increase capital imports.

As this analysis shows, financial liberalization introduces shocks to investor sentiment as a new source of macroeconomic volatility. Moreover, it is not in general the case that financial liberalization makes a country less sensitive to savings shocks and more sensitive to productivity shocks. The reason is that these shocks might affect investor sentiment leading to outcomes that are quite different from what standard theory predicts.

\subsection{Discussion}

We argued above that the conventional view is unable to explain the variety of country experiences observed after many emerging markets turned to financial liberalization in the aftermath of the debt crisis of the 1980s. We asked then whether the problem with this view could be traced to the assumption that all domestic debts are enforced even when foreign ones are not. To answer this question, we re-constructed the theory without this assumption and obtained the results discussed in the previous two sections. It seems fair to ask now whether these new theoretical results might help us achieve a better understanding of the observed effects of financial liberalization in emerging markets.

The most distinguishing aspect of the theory developed here is that the effects of financial liberalization should vary across capital-scarce countries, depending on a variety of well-identified country characteristics. In particular, we should consider two groups of countries based on whether they are below or above a threshold (which itself depends on country-specific characteristics). On the one hand, we have the set of "poor" emerging markets for which $k_{t_{L}}<\bar{\kappa}_{t}$ and optimism is not a possibility. On the other hand, we have the set of "middle-income" emerging markets for 
which $k_{t_{L}}<\bar{\kappa}_{t}$ and optimism is indeed possible. The effects of financial liberalization should vary between and also within these groups.

Consider first the case of "poor" emerging markets. The conventional view recognized that foreign sources of financing would be risky, as the temptation for opportunistic default combined with low-quality enforcement institutions were likely to generate recurrent foreign debt crisis. But even then, the ability to discriminate against foreigners would keep the domestic payments system insulated from these crises. As a result, domestic savings would stay at home still available for entrepreneurs, and the new foreign sources of financing would constitute a net addition to overall development financing. The result would invariably be higher investment and growth.

What the conventional view did not realize is that it is quite difficult to insulate domestic debts from opportunistic defaults on foreign debts. Discriminating against foreigners is not possible when foreign finance takes the form of bonds and stocks, since foreigners can resell these assets to domestic residents in secondary markets in anticipation of default. Even when financing is intermediated by banks and other financial institutions, discrimination is difficult because governments might not know the identity of their clients or how these intermediaries distribute gains/losses among them. Once domestic savers understand that defaults will not only affect foreign payments but also domestic ones, they find it optimal to send part or all of their savings abroad. This detrimental "capital flight" effect was not anticipated by the conventional view.

Financial liberalization has then unclear effects on the overall amount of financing that is available for investment and growth. It adds new foreign sources of financing that are cheap but also risky, and it also subtracts domestic sources of financing that were expensive but also safe. In really poor countries with little domestic savings to start with, this capital-flight effect is not likely to be quantitatively important and, as a result, financial liberalization is likely to add to development financing. The opposite might happen in not so poor countries with a reasonable amount of domestic savings. In these countries, the capital-flight effect might be so severe that financial liberalization does in fact subtract from development financing even if the country is capital-scarce.

Consider next the case of "middle-income" countries. The conventional view was that these countries would benefit from financial liberalization, but probably less than the first group of poor countries. The reason, of course, is that these countries already had a substantial amount of domestic savings and their needs for foreign financing were less acute. Within this group of countries, the effects of financial liberalization depend on self-fulfilling expectations. Some of them might be lucky (able?) and coordinate to the optimistic equilibrium and find that financial liberalization is surprisingly successful, well beyond what the conventional view predicted. The reason is due 
to a second effect that the conventional view did not anticipate either: optimism keeps domestic savings at home, and the fear of destroying useful domestic payments reduces or eliminates the temptation for opportunistic default. This beneficial "financial depth" effect lowers the risk of foreign borrowing, further raising capital imports, investment and growth.

Alongside these examples of successful financial liberalization, there might be other middleincome emerging markets for which financial liberalization does not work at all. Ex-ante, this second group of countries look similar to those that succeed. The difference however is that they are unlucky (unable?) and coordinate to the pessimistic equilibrium. As a result, the beneficial financial-depth effect no longer applies. Even worse, since these countries initially had a substantial amount of domestic savings the detrimental capital-flight effect is sizeable. Thus, these countries end up exporting capital and experiencing a slowdown in investment and growth.

A key aspect of the theory then is that, for middle-income countries, self-fulfilling expectations play a crucial role. This can explain not only cross-sectional variation in the data, but also the time-series variation for which country characteristics seem relatively stable. Shifts in investor sentiment can lead to sudden stops of capital imports in successful countries. Shifts in investor sentiment can also lead to large surges in capital imports in unsuccessful ones. In any case, and unlike the case of poor emerging-markets, financial liberalization is likely to raise macroeconomic volatility in middle-income emerging-markets.

Although this discussion is tentative, it illustrates the potential of the theory in explaining the findings of the empirical literature discussed in the introduction. In particular, it shows why financial liberalizations are sometimes successful and sometimes not, and how country characteristics and luck combine to determine this. With such a variety of possible experiences, it is only natural that the one-size-fits-all policy package that comes out from the conventional view is likely to fail in some countries. It is therefore important to tailor financial liberalization to the particular needs of each specific country. A full analysis of welfare and policy implications is possible and indeed quite interesting. But this would make the paper too long so we must leave it for future research. We cannot resist however concluding the paper with some speculative remarks on the theoretical insights that we have gained on how to manage financial liberalization.

\section{On how to manage financial liberalization}

The conventional view was that a policy package that combines financial liberalization with structural reforms to raise productivity and improve institutions would put any emerging market in a fast-track path to development. The theory developed here qualifies this policy recommendation 
in a fundamental way by shifting the emphasis towards the importance of domestic asset trade. Whether financial liberalization is successful or unsuccessful hinges on keeping this trade and this in turn depends on country characteristics and luck.

Obviously, structural reforms that improve these country characteristics can help making financial liberalization successful. Moreover, liberalization increases the incentives to carry out these reforms. For instance, in our model the quality of enforcement institutions does not matter in autarky but becomes crucial after financial liberalization. It would be interesting to formally model how institutions evolve and develop further results. But we leave this task for future research. Instead, we focus next on various policies that are less ambitious. ${ }^{34}$

Even if other policy instruments are not available, countries must still decide when to implement a financial liberalization. Thus, the first and most rudimentary policy choice we consider is the timing of financial liberalization. The conventional view regarding this choice is straightforward: the earlier the better! After all, this view predicts all financial liberalizations to be successful. Is there an equally simple and clearcut prediction coming from the theory developed here? At the risk of oversimplification, we would argue that this is indeed the case and that our theory says: unless the country is very poor, wait until it is ready! With pessimism, financial liberalization destroys domestic asset trade. If the country is very poor, this does not matter much because this trade was small to start with. Thus, financial liberalization still leads to capital imports and raises investment and growth in very poor countries. If the country is not very poor, the destruction of domestic asset trade is sizeable and leads to capital exports that lower investment and growth. In this case, a country should wait to liberalize until optimism is possible. Even then, the theory warns us that financial liberalization might be unsuccessful if investor sentiment turns out to be pessimistic. Being ready is a necessary but not sufficient condition for success. ${ }^{35}$

Waiting until the country has reached a sufficiently high level of development to liberalize might not be too useful a policy advice for countries that are eager to raise the living standards of their populations now and not later. Thus, a first question we must ask is: Is there any policy that can be used to sustain optimism and give financial liberalization a chance to succeed when fundamentals suggest that the country should wait? We know that, even if the country is ready,

\footnotetext{
${ }^{34}$ A caveat is in order: we do not focus on welfare and instead define a financial liberalization as "successful" if it results in capital imports.

${ }^{35}$ Of course, for this recommendation to be operational we must define what it means for a country to be "very poor" and "ready". Fortunately, the theory is quite precise about this. Recall that the discussion of the effects of financial liberalization in a country with a very low initial capital stock identified three different phases through which the country would go through. A country is very poor when its initial capital stock is low enough that financial liberalization would put the country in the first phase: $k_{t} \leq \hat{\kappa}_{t}$. A country is ready to liberalize only when its initial capital stock is high enough so that, after financial liberalization, the country would skip the first and second phases: $k_{t} \geq \bar{\kappa}_{t}$.
} 
financial liberalization might be unsuccessful if investor sentiment turns out to be pessimistic. Thus, a second question that we must ask is: Is there any policy that can be used to rule out pessimism and ensure that financial liberalization is successful? These two questions, of course, ask whether there exist policies that make the optimistic equilibrium possible and rule out the pessimistic one.

The answers to these questions are positive under certain conditions. In the model there exist two externalities associated with financial transactions. First, entrepreneurs borrow too much from foreigners, which increases the incentives to default. That is why the optimistic equilibrium does not always exist. It is easy to show that, by imposing controls on capital inflows, the country can always make the optimistic equilibrium possible. In particular, regardless of how low domestic savings are, foreign borrowing can be reduced to a low enough level so that, if domestic savings stay at home, enforcement is preferred ex-post. ${ }^{36}$ Second, savers do not lend enough domestically, which also increases the incentives to default. That is why they sometimes send their savings abroad leading to the pessimistic equilibrium. It is obvious that, by imposing controls on capital outflows, the country can always rule out the pessimistic equilibrium. ${ }^{37}$ Thus, a careful combination of controls on capital inflows and outflows would ensure that liberalization leads to capital inflows and higher investment and growth without increasing volatility as a result of multiple equilibria.

Have we then found the policy solution to the problem of financial liberalization? Unfortunately not, since we have cheated along the way. Capital controls can only be imposed if countries can discriminate between foreign and domestic agents ex-ante, at the time of borrowing. But this seems highly unlikely for the same reasons that ex-post discrimination is not realistic. For example, even if the country guarantees that entrepreneurs borrow from domestic savers, nothing prevents these savers from reselling the domestic assets to foreigners in secondary markets or swapping deposits in domestic banks with deposits in foreign banks. ${ }^{38}$

In the absence of discriminatory policies, we are left only with policies that do not directly address the externalities mentioned above. As a result, these policies tend to introduce additional distortions. Policies of this kind include limits on borrowing, limits on investment, and forced savings. A full analysis of these policies is worthwhile but would require a richer model. ${ }^{39}$

\footnotetext{
${ }^{36}$ Even if feasible, such policy might be counterproductive in countries with very low savings. The reason is that in these countries net capital inflows in such constrained optimistic equilibrium are in fact lower than in the unconstrained pessimistic equilibrium.

${ }^{37}$ When the optimistic equilibrium exists, either because $k_{t} \geq \bar{\kappa}_{t}$ or because other policies have made it possible even if $k_{t}<\bar{\kappa}_{t}$, forbidding capital outflows ensures that the optimistic equilibrium is played and $\operatorname{Pr}_{t}\left[z_{t+1}=E\right]=1$. When the optimistic equilibrium does not exist, forbidding outflows leads to a mixed strategy equilibrium with $\operatorname{Pr}_{t}\left[z_{t+1}=E\right]<1$, in which net capital inflows are either zero or positive.

${ }^{38}$ Capital controls seem feasible only if countries implement sweeping controls on all foreign financial transactions. But, in a world in which there is also a scope for international trade in goods, this would introduce additional distortions. See Broner, Martin, and Ventura (2010) and Broner and Ventura (forthcoming) for a discussion of the effects of capital controls and trade policy in such an environment.

${ }^{39}$ Note that in this model borrowing limits would have the same effect as controls on capital inflows. But this is
} 
Finally, it is worth commenting on policies that affect the degree of discrimination. During the 1970s and early 1980s, in emerging markets governments borrowed abroad almost exclusively from foreign banks using syndicated loans, while the private sector was largely shut out from international financial markets. This facilitated discrimination, as countries could choose not to pay to foreign banks without interfering with domestic asset trade. This institutional setup changed in the 1990s and 2000s. In particular, emerging markets lifted restrictions on the access of the private sector to international markets and encouraged the development of secondary markets where domestic assets can be traded. This has made discrimination much more difficult. This shows that, to some extent, countries can design their financial systems so as to achieve a certain degree of discrimination.

The theory proposed in this paper has clear implications regarding the degree of discrimination that makes financial liberalization more likely to succeed. A country at an early stage of development should adopt a financial system that facilitates discrimination, since this leads to higher capital inflows, investment, and growth. The reason is that with discrimination domestic financial markets remain isolated from enforcement problems affecting foreign debts and the "capital flight" effect is avoided. A country at a late stage of development should adopt a financial system that makes discrimination difficult as this leads on average to higher capital inflows, investment, and growth. ${ }^{40}$ In this case, the "financial depth" effects dominates and the country can leverage on its domestic financial markets to take better advantage of its access to international financial markets. Interestingly, this is a possible explanation for the change in the institutional setup for emerging market borrowing observed in the early 1990s, which has been taken largely as exogenous by the previous literature.

\section{References}

[1] Abel, A., G. Mankiw, L. Summers, and R. Zeckhauser, (1989). "Assessing dynamic efficiency: Theory and evidence," Review of Economic Studies 56, 1-19

[2] Acemoglu, D., and F. Zilibotti, (1997). "Was Prometheus unbound by chance? Risk, diversification and growth," Journal of Political Economy 105, 709-51

only because the marginal lender is foreign. In general, borrowing limits affect both foreign and domestic borrowing, so their effect on enforcement is ambiguous. See Broner and Ventura (forthcoming). Note also that borrowing limits are in general superior to borrowing taxes, since taxes generate distortions in the pessimistic equilibrium.

${ }^{40}$ Broner, Martin, and Ventura (2010) show that there are conditions under which the ability to retrade assets in secondary markets has even stronger effects than making discrimination among creditors difficult. In particular, by allowing assets to be retraded before enforcement decisions are made, secondary markets have the potential to redistribute assets in a way that maximizes the incentives to enforce. This suggests that by encouraging even further the development of liquid secondary markets, enforcement problems might be ameliorated for all stages of development, thereby increasing growth and lowering volatility. 
[3] Aguiar, M., and M. Amador, (forthcoming). "Growth in the shadow of expropriation," Quarterly Journal of Economics

[4] Aguiar, M., M. Amador, and G. Gopinath, (2009). "Investment cycles and sovereign debt overhang," Review of Economic Studies 76, 1-31

[5] Aguiar, M., and G. Gopinath, (2006). "Defaultable debt, interest rates, and the current account," Journal of International Economics 69, 64-83

[6] Aguiar, M., and G. Gopinath, (2007). "Emerging market business cycles: The cycle is the trend," Journal of Political Economy 115, 69-102

[7] Alfaro, L., S. Kalemli-Ozcan, and V. Volosovych, (2008). "Why doesn’t capital flow from rich to poor countries? An empirical investigation," Review of Economics and Statistics 90, 347-68

[8] Amador, M., (2008). "Sovereign debt and the tragedy of the commons," mimeo, Stanford

[9] Antras, P., and R. Caballero, (2009). "Trade and capital flows: A financial frictions perspective," Journal of Political Economy 117, 701-44

[10] Aoki, A., G. Benigno, and N. Kiyotaki, (2006). "Adjusting to capital account liberalization," mimeo, LSE

[11] Arellano, C., (2008). "Default risk and income fluctuations in emerging economies," American Economic Review 99, 690-712

[12] Arteta, C., B. Eichengreen, and C. Wyplosz, (2001). "When does capital account liberalization help more than it hurts?" in Capital Flows and Crises, MIT Press, 71-96

[13] Atkeson, A., (1991). "International lending with moral hazard and risk of repudiation," Econometrica 59, 1069-89

[14] Bai, Y., and J. Zhang, (2010). "Solving the Feldstein-Horioka puzzle with financial frictions," Econometrica 78, 603-32

[15] Banerjee, A., and E. Duflo, (2005). "Growth theory through the lens of Development Economics," in P. Aghion and S. Durlauf (eds.) Handbook of Economic Growth, 473-552

[16] Basu, S., (2010), "Sovereign debt and domestic economic fragility," mimeo, IMF.

[17] Bekaert, G., C. Harvey, and C. Lundblad, (2005). "Does financial liberalization spur growth?" Journal of Financial Economics 77, 3-55 
[18] Bekaert, G., C. Harvey, and C. Lundblad, (2006). "Growth volatility and financial liberalization," Journal of International Money and Finance 25, 370-403

[19] Bonfiglioli, A., (2008). "Financial integration, productivity and capital accumulation," Journal of International Economics 76, 337-55

[20] Borensztein, E., and U. Panizza, (2008). "The costs of sovereign default," IMF Working Paper $08 / 238$

[21] Boyd, J., and B. Smith, (1997). "Capital market imperfections, international credit markets, and nonconvergence," Journal of Economic Theory 73, 335-64

[22] Broner, F., A. Martin, and J. Ventura, (2008). "Enforcement problems and secondary markets," Journal of the European Economic Association 6, 683-94

[23] Broner, F., A. Martin, and J. Ventura, (2010). "Sovereign risk and secondary markets," American Economic Review 100, 1523-55

[24] Broner, F., and R. Rigobon, (2006). "Why are capital flows so much more volatile in emerging than in developed countries?" in R. Caballero et al. (eds.) External Financial Vulnerability and Preventive Policies, Central Bank of Chile

[25] Broner, F., and J. Ventura, (forthcoming). "Globalization and risk sharing," Review of Economic Studies

[26] Brutti, F., (2008). "Legal enforcement, public supply of liquidity and sovereign risk," mimeo, Universitat Pompeu Fabra

[27] Bulow, J., and K. Rogoff, (1989a). "Sovereign debt: Is to forgive to forget?" American Economic Review 79, 43-50

[28] Bulow, J., and K. Rogoff, (1989b). “A constant recontracting model of sovereign debt," Journal of Political Economy 97, 155-78

[29] Caballero, R., E. Farhi, and P. Gourinchas, (2008). "An equilibrium model of 'global imbalances' and low interest rates," American Economic Review 98, 358-93

[30] Caballero, R., and A. Krishnamurthy, (2001). "International and domestic collateral constraints in a model of emerging market crises," Journal of Monetary Economics 48, 513-48

[31] Caselli, F., and J. Feyrer, (2007). "The marginal product of capital," Quarterly Journal of Economics 122, 535-68 
[32] Cole, H., and P. Kehoe, (1997). "Reviving reputation models of international debt," Federal Reserve Bank of Minneapolis Quarterly Review 21, 21-30

[33] Díaz-Alejandro, C., (1985). "Good-bye financial repression, hello financial crash," Journal of Development Economics 19, 1-24

[34] Dixit, A., (2003). "Trade expansion and contract enforcement," Journal of Political Economy 111, 1293-317

[35] Dornbusch, R., I. Goldfajn, and R. Valdés, (1995). "Currency crises and collapses," Brookings Papers on Economic Activity 1995, 219-70

[36] Eaton, J., and R. Fernández, (1995). "Sovereign debt," in G. Grossman and K. Rogoff (eds.), Handbook of International Economics III, Elsevier

[37] Eaton, J., and M. Gersovitz, (1981). "Debt with potential repudiation: Theory and empirical analysis," Review of Economic Studies 48, 289-309

[38] Edwards, S., (2001). "Capital mobility and economic performance: Are emerging countries different?" in H. Siebert (ed.) The World's New Financial Landscape: Challenges for Economic Policy, Kiel Institute, 219-44

[39] Gennaioli, N., A. Martin, and S. Rossi, (2009). "Institutions, public debt, and foreign finance," mimeo, CREI

[40] Gertler, M., and K. Rogoff, (1990). "North-South lending and endogenous domestic capital market inefficiencies," Journal of Monetary Economics 26, 245-66

[41] Gourinchas, P. O., and O. Jeanne, (2009). "Capital flows to developing countries: The allocation puzzle," mimeo Berkeley

[42] Grossman, H., and J. Van Huyck, (1988). "Sovereign debt as a contingent claim: Excusable default, repudiation, and reputation," American Economic Review 78, 1088-97

[43] Guembel, A., and O. Sussman, (2009). "Sovereign debt without default penalties," Review of Economic Studies 76, 1297-320

[44] Henry, P., (2007). "Capital account liberalization: Theory, evidence, and speculation," Journal of Economic Literature 65, 887-935

[45] Kaminsky, G., and C. Reinhart, (1999). "The twin crises: The causes of banking and balanceof-payments problems," American Economic Review 89, 473-500 
[46] Karolyi, G., and R. Stultz, (2003). "Are financial assets priced locally or globally?," in G. Constantinides et al. (eds.) Handbook of the Economics of Finance, Elsevier

[47] Kletzer, K., and B. Wright, (2000). "Sovereign debt as intertemporal barter," American Economic Review 90, 621-39

[48] Kose, M., E. Prasad, K. Rogoff, and S. Wei, (2009). "Financial globalization: A reappraisal," IMF Staff Papers 56, 8-62

[49] Kose, M., E. Prasad, and M. Terrones, (2003). "Financial integration and macroeconomic volatility," IMF Staff Papers 50, 119-42

[50] Kraay, A., and J. Ventura, (2000). "Current accounts in debtor and creditor countries," Quarterly Journal of Economics 115, 1137-66

[51] Kraay, A., and J. Ventura, (2002). "Current accounts in the long and short run," NBER Macroeconomics Annual 2001, 65-94

[52] Kraay, A., N. Loayza, L. Servén and, J. Ventura, (2005). "Country portfolios," Journal of the European Economic Association 3, 914-45

[53] Kremer, M., and P. Mehta, (2000). "Globalization and international public finance," NBER Working Paper 7575

[54] Levchenko, A., R. Ranciere, and M. Thoenig, (2009). "Growth and risk at the industry level: The real effects of financial liberalization," Journal of Development Economics 89, 210-22

[55] Lewis, K., (1999). "Trying to explain home bias in equities and consumption," Journal of Economic Literature 37, 571-608

[56] Lucas, R., (1990). "Why doesn't capital flow from rich to poor countries?" American Economic Review 80, 92-6

[57] Martin, A., and F. Taddei, (2010). "International capital flows and credit market imperfections: A tale of two frictions," mimeo, CREI

[58] Martin, A., and J. Ventura, (2010). "Economic growth with bubbles," mimeo, CREI

[59] Martin, P., and H. Rey, (2006). "Globalization and emerging markets: With or without crash?" American Economic Review 96, 1631-51 
[60] Matsuyama, K., (2004). "Financial market globalization, symmetry-breaking and endogenous inequality of nations," Econometrica 72, 853-84

[61] Matsuyama, K., (2008). "Aggregate implications of credit market imperfections," NBER Macroeconomics Annual 2007, 1-60

[62] Mendoza, E., V. Quadrini, and J. Rios-Rull, (2009). "Financial integration, financial development, and global imbalances," Journal of Political Economy 117, 371-416

[63] Obstfeld, M., (2009). "International finance and growth in developing countries: What have we learned?" IMF Staff Papers 56, 63-111

[64] Obstfeld, M., and K. Rogoff, (1996). Foundations of International Macroeconomics, MIT Press

[65] Obstfeld, M., and A. Taylor, (2004). Global capital markets: Integration, crisis, and growth, Cambridge University Press

[66] Papaioannou, E., (2009). "What drives international financial flows? Politics, institutions and other determinants," Journal of Development Economics 88, 269-81

[67] Prasad, E., R. Rajan, and A. Subramanian, (2007). "Foreign capital and economic growth," Brookings Papers on Economic Activity 2007, 153-209

[68] Ranciere, R., A. Tornell, and F. Westermann, (2008). "Systemic crises and growth," Quarterly Journal of Economics 123, 359-406

[69] Rappoport, V., (2005). "Idiosyncratic and aggregate risk in the presence of government's moral hazard," mimeo, Columbia

[70] Reinhart, C., and K. Rogoff, (2009). This time is different: Eight centuries of financial folly, Princeton University Press

[71] Rodrik, D., (1998). "Who needs capital account convertibility?" Princeton Essays in International Finance 207, 55-65

[72] Sercu, P., and R. Vanpée, (2007). "Home bias in international equity portfolios," mimeo, Leuven School of Business and Economics

[73] Shleifer, A., and D. Wolfenzon, (2002). "Investor protection and equity markets," Journal of Financial Economics 66, 3-27 
[74] Tirole, J., (2003). "Inefficient foreign borrowing: A dual- and common-agency perspective," American Economic Review 93, 1678-702

[75] Ventura, J., (2003). "Towards a theory of current accounts," The World Economy 26, 483-512

[76] Wright, M., (2002). "Reputations and sovereign risk," mimeo, UCLA

\section{Appendix}

In the conventional view of Section 1, generation $t$ maximizes utility as described in Equation (1) subject to the budget constraints in Equations (9) and (10) and the additional constraints that $k_{t+1} \geq 0, b_{t+1}^{*} \geq 0$ and $b_{t+1} \leq 0$. When solving this problem, generation $t$ takes asset returns and the probability of enforcement as given. Let $c_{t, t+1}^{E}$ and $c_{t, t+1}^{N}$ denote consumption during old age if $z_{t+1}=E$ and $z_{t+1}=N$, respectively. After substituting the budget constraints into the utility function, this maximization problem yields the following Kuhn-Tucker conditions:

1. Maximization with respect to $k_{t+1}$ :

$$
\begin{aligned}
& \left(\frac{u^{\prime}\left(c_{t, t}\right)}{A}-\beta \cdot r_{t+1} \cdot\left(\operatorname{Pr}_{t}\left[z_{t+1}=E\right] \cdot u^{\prime}\left(c_{t, t+1}^{E}\right)+\left(1-\operatorname{Pr}_{t}\left[z_{t+1}=E\right]\right) \cdot u^{\prime}\left(c_{t, t+1}^{N}\right)\right)\right) \cdot k_{t+1}=0 \\
& \text { with } k_{t+1} \geq 0 \text { and } \frac{u^{\prime}\left(c_{t, t}\right)}{A} \geq \beta \cdot r_{t+1} \cdot\left(\operatorname{Pr}_{t}\left[z_{t+1}=E\right] \cdot u^{\prime}\left(c_{t, t+1}^{E}\right)+\left(1-\operatorname{Pr}_{t}\left[z_{t+1}=E\right]\right) \cdot u^{\prime}\left(c_{t, t+1}^{N}\right)\right) .
\end{aligned}
$$

2. Maximization with respect to $b_{t+1}$ :

$$
\left(\frac{u^{\prime}\left(c_{t, t}\right)}{R_{t+1}}-\beta \cdot \operatorname{Pr}_{t}\left[z_{t+1}=E\right] \cdot u^{\prime}\left(c_{t, t+1}^{E}\right)\right) \cdot b_{t+1}=0
$$

with $b_{t+1} \leq 0$ and $\frac{u^{\prime}\left(c_{t, t}\right)}{R_{t+1}} \leq \beta \cdot \operatorname{Pr}_{t}\left[z_{t+1}=E\right] \cdot u^{\prime}\left(c_{t+1}^{E}\right)$.

3. Maximization with respect to $b_{t+1}^{*}$ :

$$
\begin{gathered}
\left(\frac{u^{\prime}\left(c_{t, t}\right)}{R_{t+1}^{*}}-\beta \cdot\left(\operatorname{Pr}_{t}\left[z_{t+1}=E\right] \cdot u^{\prime}\left(c_{t, t+1}^{E}\right)+\left(1-\operatorname{Pr}_{t}\left[z_{t+1}=E\right]\right) \cdot u^{\prime}\left(c_{t, t+1}^{N}\right)\right)\right) \cdot b_{t+1}^{*}=0 \\
\text { with } b_{t+1}^{*} \geq 0 \text { and } \frac{u^{\prime}\left(c_{t, t}\right)}{R_{t+1}^{*}} \geq \beta \cdot\left(\operatorname{Pr}_{t}\left[z_{t+1}=E\right] \cdot u^{\prime}\left(c_{t, t+1}^{E}\right)+\left(1-\operatorname{Pr}_{t}\left[z_{t+1}=E\right]\right) \cdot u^{\prime}\left(c_{t, t+1}^{N}\right)\right) .
\end{gathered}
$$

We can use these first-order conditions plus Equations (2), (7) and (8) to prove the four intermediate results in the text. We first make two observations: 
- It must be the case that $k_{t+1}>0$. Assume instead that $k_{t+1}=0$. Then, it follows from Equations (2) and (7) that $r_{t+1}>R_{t+1}^{*}$. It also follows that $b_{t+1}^{*}>0$ and thus $\frac{u^{\prime}\left(c_{t, t}\right)}{R_{t+1}^{*}}=$ $\beta \cdot\left(\pi \cdot u^{\prime}\left(c_{t, t+1}^{E}\right)+(1-\pi) \cdot u^{\prime}\left(c_{t, t+1}^{N}\right)\right)$. But these observations together imply that $\frac{u^{\prime}\left(c_{t, t}\right)}{A}<$ $\beta \cdot r_{t+1} \cdot\left(\pi \cdot u^{\prime}\left(c_{t, t+1}^{E}\right)+(1-\pi) \cdot u^{\prime}\left(c_{t, t+1}^{N}\right)\right)$ and this is incompatible with the assumption that $k_{t+1}=0$. Therefore, $k_{t+1}>0$.

- It must be the case that either $b_{t+1}^{*}>0$ or $b_{t+1}<0$, but not both. Assume instead that $b_{t+1}^{*}>0$ and $b_{t+1}<0$. Then, it follows from the second and third Kuhn-Tucker conditions that $u^{\prime}\left(c_{t+1}^{E}\right)=u^{\prime}\left(c_{t+1}^{N}\right)$. But this is incompatible with the assumption that $b_{t+1}<0$. Therefore, either $b_{t+1}<0$ or $b_{t+1}^{*}>0$, but not both.

These observations allow us to focus on two relevant cases. The first one is that in which $k_{t+1}>0, b_{t+1}^{*} \geq 0$ and $b_{t+1}=0$. Substituting Equations (2), (7) and (8) into the first and third Kuhn-Tucker conditions and manipulating the resulting two-equation system yields:

$$
\begin{gathered}
A \cdot \alpha \cdot k_{t+1}^{\alpha-1}=1 \\
\frac{k_{t+1}}{A}+b_{t+1}^{*}=s \cdot k_{t}^{\alpha}
\end{gathered}
$$

This case applies if and only if $A \cdot s \cdot k_{t}^{\alpha} \geq(\alpha \cdot A)^{\frac{1}{1-\alpha}}$. Otherwise we would reach the contradiction that $b_{t+1}^{*}<0$.

The second relevant case is that in which $k_{t+1}>0, b_{t+1}^{*}=0$ and $b_{t+1} \leq 0$. Substituting Equations (2), (7) and (8) into the first and second Kuhn-Tucker conditions and manipulating this two-equation system yields:

$$
\begin{gathered}
A \cdot \alpha \cdot k_{t+1}^{\alpha-1}=1+(1-\pi) \cdot \frac{\left(-b_{t+1}\right)}{k_{t+1} / A} \\
\frac{k_{t+1}}{A}+\pi \cdot b_{t+1}=s \cdot k_{t}^{\alpha}
\end{gathered}
$$

This case applies if and only if $A \cdot s \cdot k_{t}^{\alpha} \leq(\alpha \cdot A)^{\frac{1}{1-\alpha}}$. Otherwise we would reach the contradiction that $b_{t+1}>0$. 


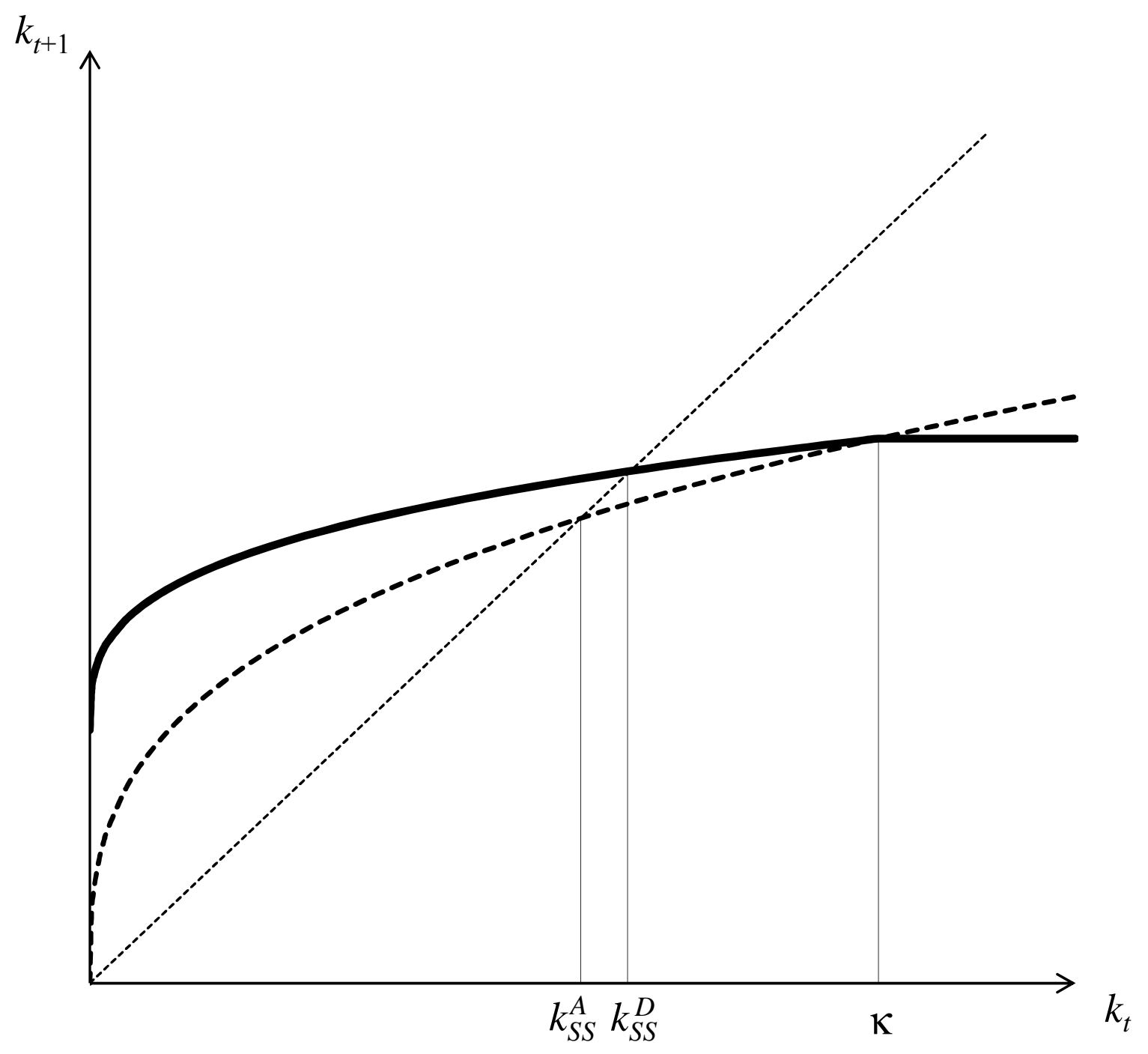

Figure 1: Laws of Motion under Conventional View 


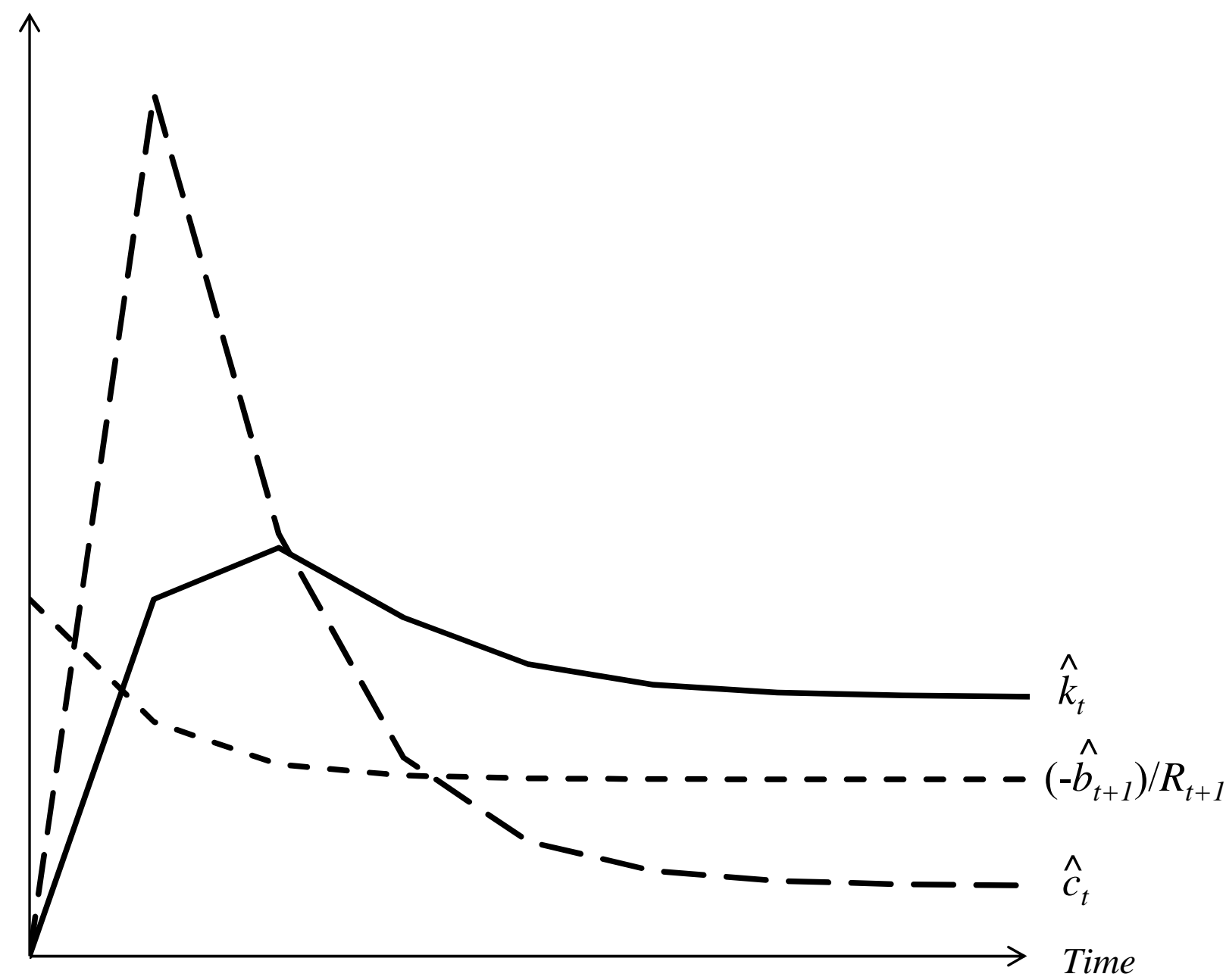

Figure 2: Effects of Financial Liberalization under Conventional View 

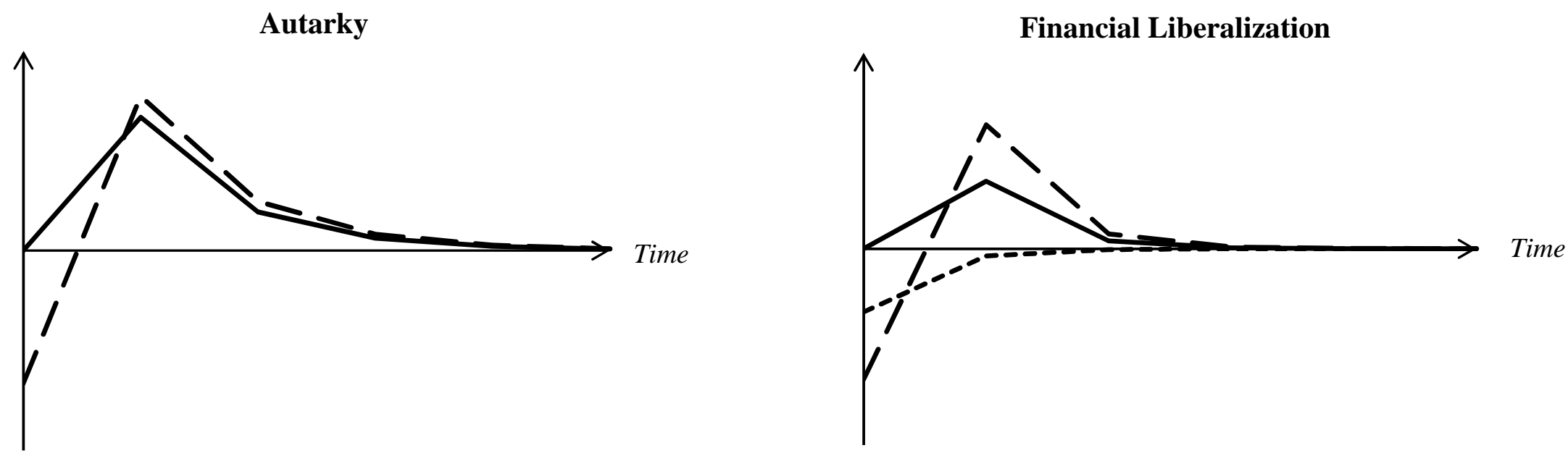

(a) Transitory shock to $s$
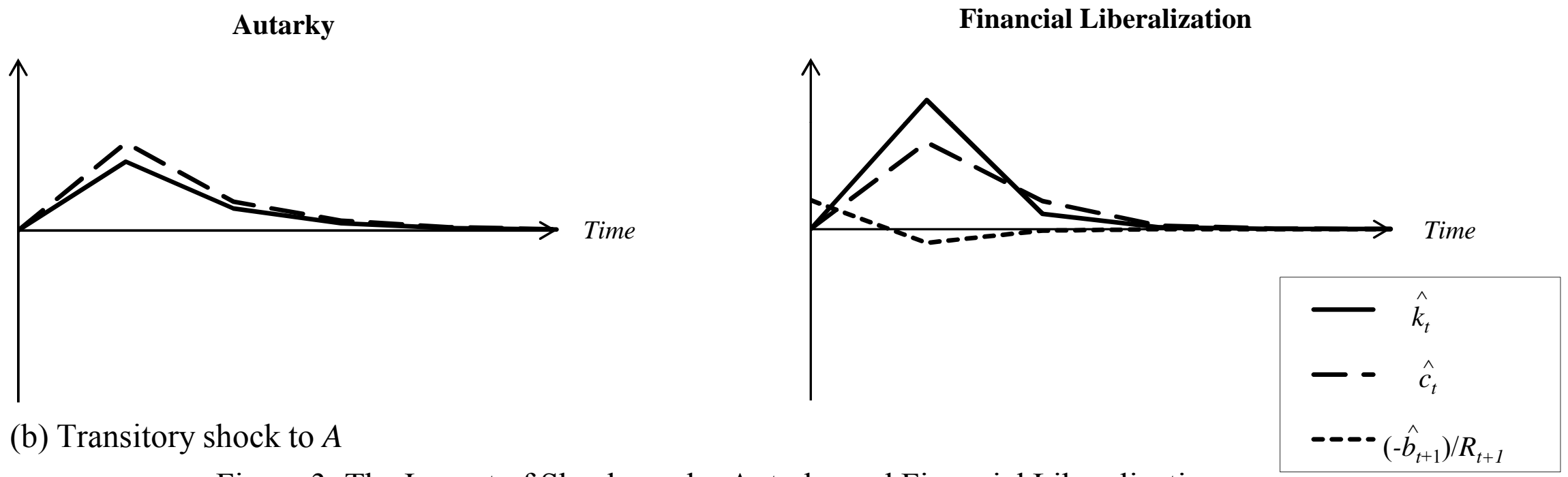

(b) Transitory shock to $A$

Figure 3: The Impact of Shocks under Autarky and Financial Liberalization 


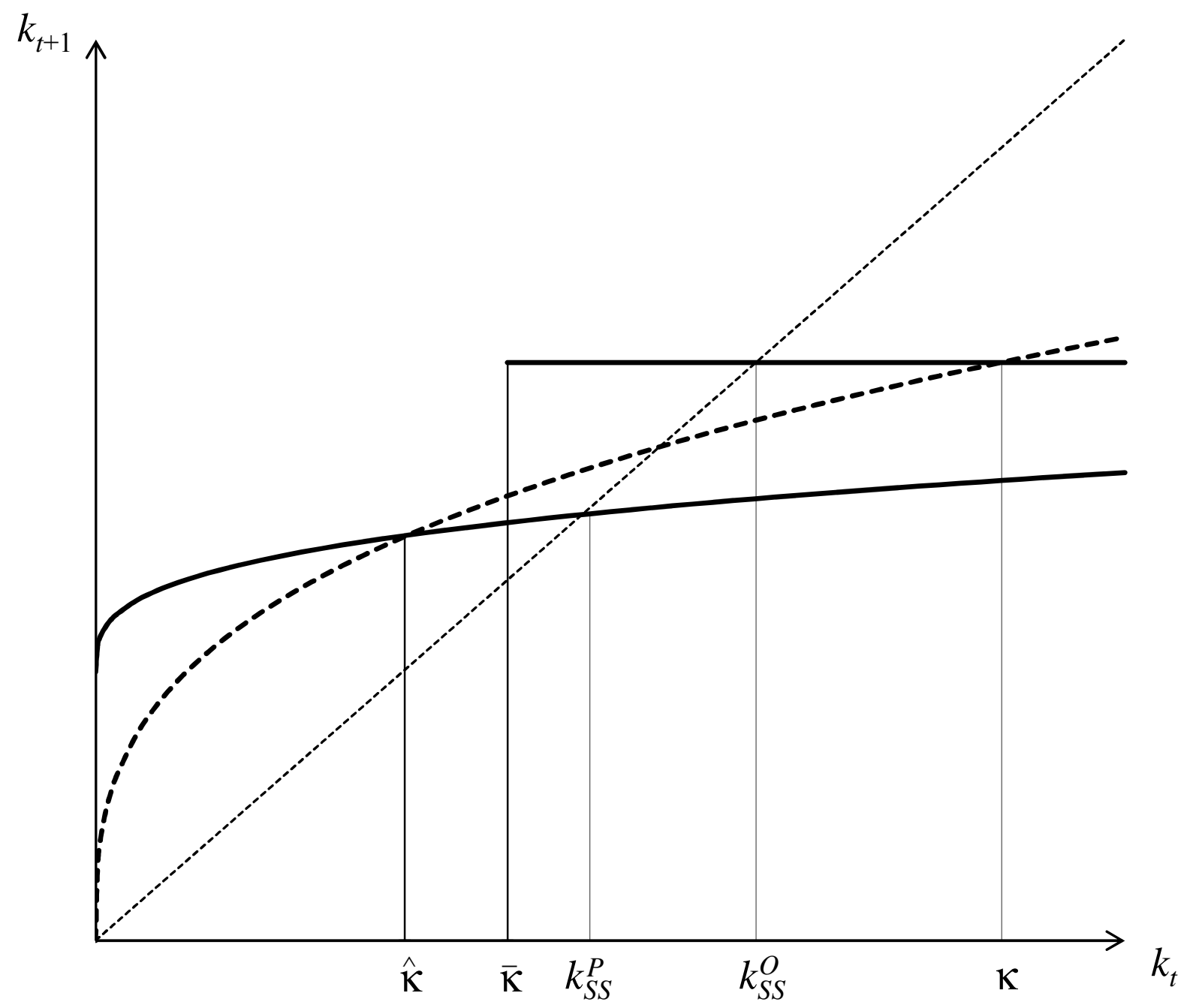

Figure 4: Laws of Motion with Domestic Asset Trade and Non-Discrimination 


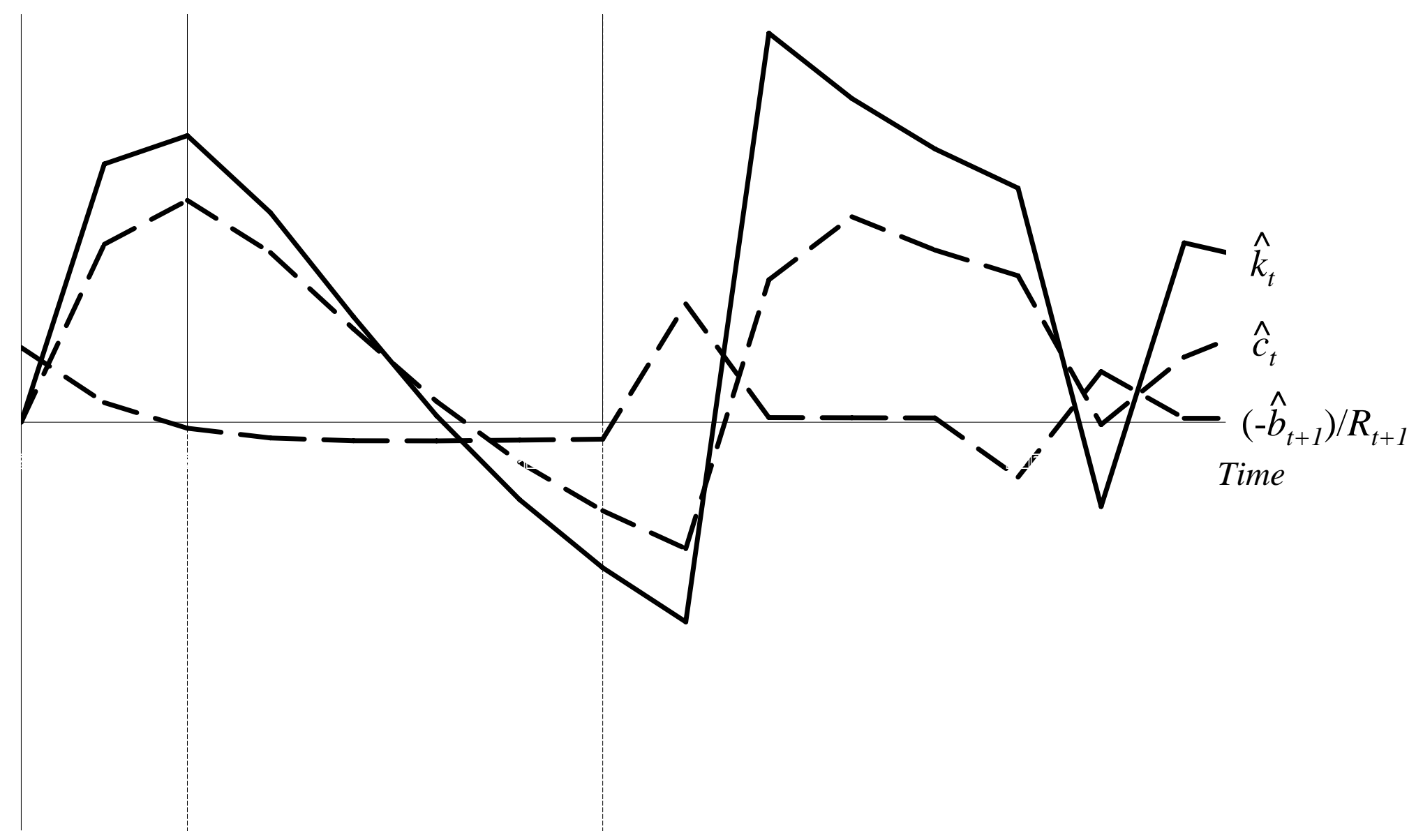

Phase I

Phase II

Phase III

Figure 5: Effects of Financial Liberalization without Discrimination 


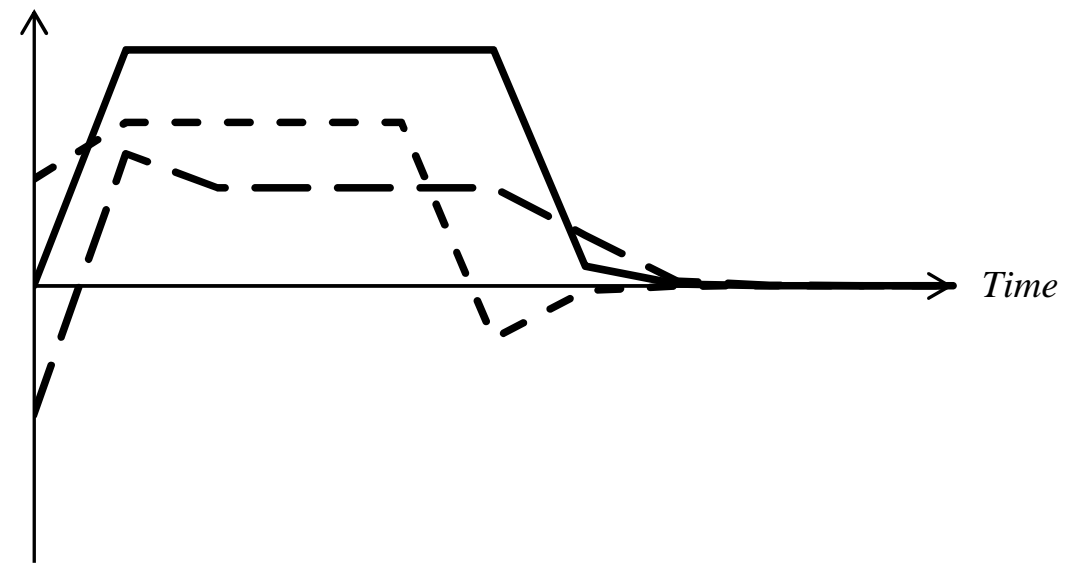

(i) Positive savings shock leading to optimism

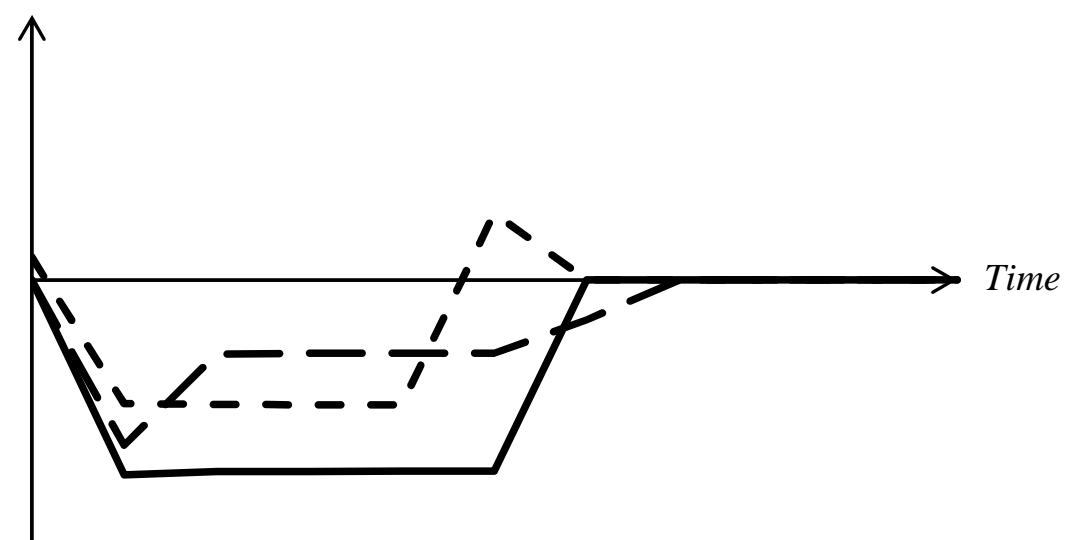

(iii) Positive productivity shock leading to pessimism

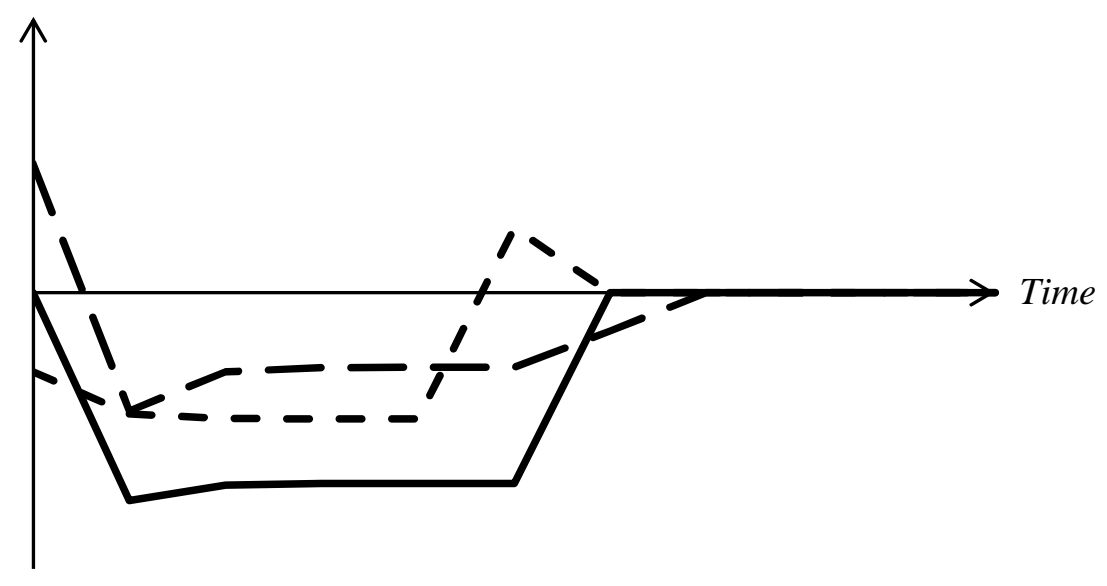

(ii) Negative savings shock leading to pessimism

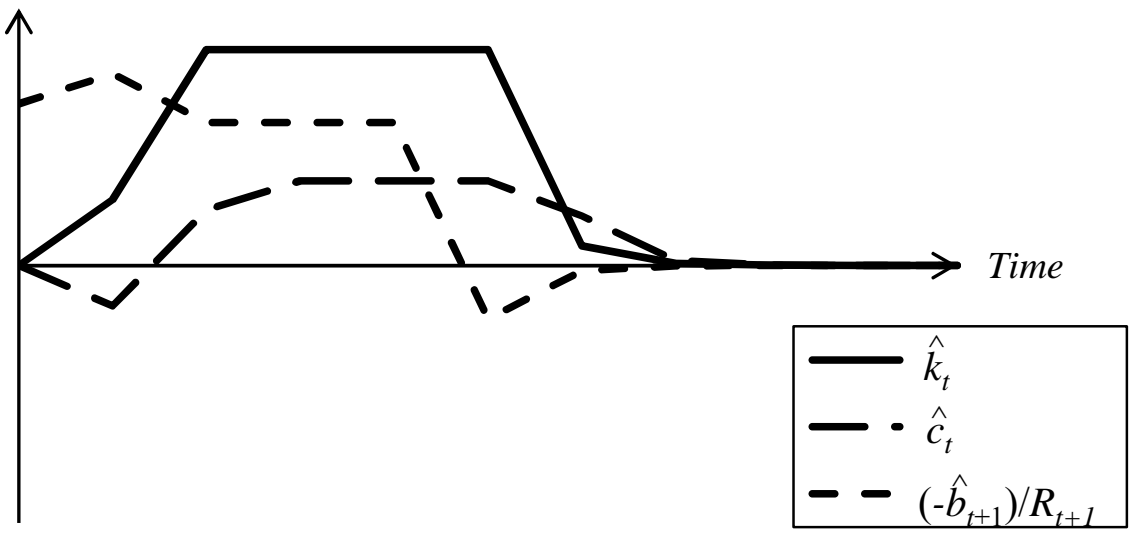

(iv) Negative productivity shock leading to optimism

Figure 6: Shocks under Financial Liberalization without Discrimination

Notes: $\hat{x}_{t}$ describes the deviation of variable $x_{t}$ from its steady state value, normalized by the economy's steady-state GDP. In panels (i) and (iv), the economy starts in the pessimistic equilibrium and the shock makes the optimistic equilibrium feasible, which is then played for several periods. Eventually, a period of pessimism returns the economy to its original steady state. In panels (ii) and (iii), the economy starts in the optimistc equilibrium and the shock makes this equilibrium temporarily infeasible. The economy returns to it as soon as it becomes feasible again. 